Review

\title{
Review on the application of modified iron oxides as heterogeneous catalysts in Fenton reactions
}

\author{
Shima Rahim Pouran ${ }^{1}$, Abdul Aziz Abdul Raman*, Wan Mohd Ashri Wan Daud ${ }^{2}$ \\ Chemical Engineering Department, Faculty of Engineering, University of Malaya, 50603 Kuala Lumpur, Malaysia
}

\section{A R T I C L E I N F O}

\section{Article history:}

Received 6 March 2013

Received in revised form

31 August 2013

Accepted 10 September 2013

Available online 18 September 2013

\section{Keywords:}

Heterogeneous catalyst

Transition metal substituted iron oxide

Redox pairs

Oxygen vacancies

\begin{abstract}
A B S T R A C T
Heterogeneous Fenton reaction is an advanced oxidation process which has gained wide spread acceptance for higher removal efficiency of recalcitrant organic contaminants under wide range of $\mathrm{pH}$ compared to homogeneous reactions. Conventionally, iron oxides are used as heterogeneous catalysts for Fenton oxidation system because of their abundance, easy separation and lower cost. This paper reviews the substitution of iron in an iron oxide with other transition metals as a mean to improve the properties of the iron oxide towards higher performance for contaminant degradation. Several studies have reported enhanced performance resulted from this substitution based on two possible mechanisms. First is the conjugation of redox pairs of iron species and imported active ion in hydroxyl radical production cycle. Second: the generation of oxygen vacancies as active sites on the surface of catalyst via adjustments for unequal charge substitutions. This class of catalysts is anticipated to work effectively for treatment of various recalcitrant wastewaters using Fenton oxidation system. Subsequently, the stability of the produced catalyst needs to be examined under various experimental conditions to prevent the adverse effects of transition metals on the receiving environment.
\end{abstract}

(c) 2013 Elsevier Ltd. All rights reserved.

\section{Introduction}

Water pollution abatement and treatment of wastewaters carrying recalcitrant contaminants have been major issues for decades. Recalcitrant compounds are generally of high molecular weight and hydrophobic in nature. It poses high resistance to microbiological degradation (Alexander, 1975) and may not be degraded readily by biological treatment methods. Large number of pharmaceutical and agrochemical compounds are recalcitrant. Discharge of these recalcitrant compounds to the environment even in small quantities may eventually lead to accumulate in ecosystem (Knapp and Bromley-Challoner, 2003). Many of recalcitrant compounds are

Abbreviations: AOPs, advanced oxidation processes; $\mathrm{AV} *$, anion vacancies; $\mathrm{BET}$ Brunauer-Emmett-Teller; $C$, Carbon; CA, chelating agents; $C M C D$, carboxymethyl- $\beta$ cyclodextrin; DMP, dimethyl phthalate; EDTA, Ethylene diamine tetraacetic acid; $\mathrm{MB}$, methylene blue; MIMS, membrane introduction mass spectrometry; ${ }^{\bullet} \mathrm{OH}$, hydroxyl radical; PCP, pentachlorophenol; SSA, surface area per unit mass; $t_{1 / 2}$, halflives; T, tesla; TMSIO, transition metal substituted iron oxide; TNT, 2,4,6trinitrotoluene; TOC, Total organic carbon; UV-Vis, Ultraviolet-visible light region.

* Corresponding author. Tel.: +60 3 79675313, +60 3 79675300; fax: +60 3 79675319

E-mail addresses: rahimpooran@yahoo.com (S. Rahim Pouran), rshazrin@gmail.com, azizraman@um.edu.my (A.A. Abdul Raman), ashri@um.edu.my (W.M.A. Wan Daud).

1 Tel.: +60 3796 75206; fax: +60 379675319

2 Tel.: +60 3 79675297; fax: +60 379675319 . capable to directly or indirectly affect living organisms including human being. Some examples are revelation of antibiotic-resistant bacteria (Walter and Vennes, 1985), interfering the human endocrine system (Bredhult et al., 2007) and oxidative stress on fish (Laville et al., 2004). To prevent their adverse effects, the attempt should encompass minimisation of recalcitrant wastewaters from industries (Klemeš et al., 2012) as well as enhancement in treatment technologies such as advanced oxidation processes (AOPs). AOPs have been applied for degradation and mineralisation of organic pollutants such as phenolic compounds (Babuponnusami and Muthukumar, 2011; Ortiz de la Plata et al., 2010), pharmaceuticals (Valcárcel et al., 2012), agrochemicals (Silva et al., 2012) landfill leachate (Rocha et al., 2011) and also for feasible and enhanced treatment of decentralised wastewaters (Chong et al., 2012). These processes were found to be environmentally sustainable if the process energy consumption was low (Chatzisymeon et al., 2013). Fenton process is a strong oxidation system amongst advanced oxidation processes and has been successfully put into use for removal of recalcitrant organic contaminants (Ortiz de la Plata et al., 2010; Rocha et al., 2011). This process is known as the reaction between hydrogen peroxide as an oxidant and iron ions as a catalyst to produce highly active species, mainly non-selective - $\mathrm{OH}$ radicals with oxidation potential of $2.8 \mathrm{~V}$ (Haber and Weiss, 1934), as shown in Equations (1) and (2) (Pignatello et al., 2006): 


$$
\begin{aligned}
& \mathrm{H}_{2} \mathrm{O}_{2}+\mathrm{Fe}^{2+} \rightarrow \mathrm{Fe}^{3+}+{ }^{-} \mathrm{OH}+{ }^{\circ} \mathrm{OH} \quad \mathrm{k}=63 \mathrm{M}^{-1} \mathrm{~s}^{-1} \\
& \mathrm{H}_{2} \mathrm{O}_{2}+\mathrm{Fe}^{3+} \rightarrow \mathrm{Fe}^{2+}+\mathrm{HO}_{2}+\mathrm{H}^{+} \quad k=0.002-0.01 \mathrm{M}^{-1} \mathrm{~s}^{-1}
\end{aligned}
$$

Photo-Fenton reaction is a combination of Fenton reagents and UV-Vis light that brings about additional ${ }^{\circ} \mathrm{OH}$ radicals via (i) photoreduction of ferric ions to ferrous ions and (ii) hydrogen peroxide photolysis (Pignatello et al., 2006). The optimal pH value of 3 is accepted for Fenton process in which the quantum yield of $\cdot \mathrm{OH}$ radical generation at this value is the most (Benkelberg and Warneck, 1995). At higher $\mathrm{pH}$ values than optimal value and/or at higher concentrations of $\mathrm{H}_{2} \mathrm{O}_{2}(>1 \%)$, other non-hydroxyl radicals that are less active in oxidation of contaminants when compared to -OH radicals are also formed (Pignatello et al., 2006; Watts and Teel, 2006). The Fenton reaction in which iron salts are used as catalyst is defined as homogeneous Fenton process. In homogeneous Fenton oxidation systems, mass transfer limitations are negligible and the readily available iron ion in the reaction medium reacts effectively in the degradation process. However, there are some drawbacks encountered by this process that are mainly (i) pH-dependence of the system (2.5-4.0), (Katsumata et al., 2005) (ii) formation of ferric hydroxide sludge at pH values above 4.0 (Tamimi et al., 2008) and its removal issue (iii) the generated sludge may prevent UV radiation penetration in photo-Fenton process (Faust and Hoigne, 1990) which will affect treatment process (iv) difficulty in catalyst recovery (Pariente et al., 2008) and (v) the cost associated with acidification and subsequent neutralization that may limit the application of homogeneous Fenton oxidation system at industrial scale. Therefore, the application of heterogeneous Fenton reactions as a possible solution to overcome the shortcomings of homogeneous catalysis has been put into perspectives by many researchers. This will enable pollutant mineralisation under non-controlled $\mathrm{pH}$ conditions and also for contaminated sites with $\mathrm{pH}$ adjustment limitations (Usman et al., 2012b). In heterogeneous catalysis, iron is stabilised within the interlayer space of the catalyst's structure and can effectively produce hydroxyl radicals from oxidation of hydrogen peroxide, under non-controlled $\mathrm{pH}$ conditions and without iron hydroxide precipitation (Garrido-Ramírez et al., 2010). Several heterogeneous catalysts have been employed in Fenton reactions such as mesoporous materials (Chun et al., 2012; Xia et al., 2011), iron pillared clays (Chen et al., 2010), iron containing zeolites (Dükkanc1 et al., 2010; Hassan and Hameed, 2011) and iron minerals (Lan et al., 2010; Magalhães et al., 2007; Ortiz de la Plata et al., 2010). There have been extensive studies on application of iron oxides in pure or structurally modified forms. At present time, several important reviews have been reported in the literature on the basic facets and applications of iron bearing minerals as active catalyst or support (Garrido-Ramírez et al., 2010) and also iron oxide nanomaterials in heterogeneous catalytic reactions for organic contaminant degradation (Soon and Hameed, 2011; Xu et al., 2012) and heavy metal removal from polluted sites and wastewaters (Hua et al., 2012). However, the recent reported findings on modified iron minerals and their structural changes toward effective contaminant removal have not been discussed in detail in any of past reviews reported in the literature. Therefore, this review aims at giving an account of fundamental aspects of different iron oxides as follows: Section 2 discusses the merits of different iron oxides and their applications as heterogeneous catalysts in Fenton treatment system. Section 3 introduces transition metal substituted iron oxides (TMSIOs) as a catalyst with higher performance in degradation of organic pollutants. In terms of TMSIOs, valence and occupied sites, changes in physico-chemical properties, adsorption capacity and catalytic activity are discussed in detail in the next sections. Section 4 provides a summary and conclusion of the review and subsequently, suggestions are given for plausible research directions.

\section{Iron oxides in wastewater treatment}

Iron oxides are abundantly available minerals present in the earth crust. Out of the sixteen known iron oxides and hydroxides (Cornell and Schwertmann, 2003), magnetite $\left(\mathrm{Fe}_{3} \mathrm{O}_{4}\right)$, goethite $(\alpha \mathrm{FeOOH})$, maghemite $\left(\gamma \mathrm{Fe}_{2} \mathrm{O}_{3}\right)$ and hematite $\left(\alpha \mathrm{Fe}_{2} \mathrm{O}_{3}\right)$ are widely used in heterogeneous catalysis processes and have been attractive alternatives for remediation of polluted soil, groundwater (Aredes et al., 2012) and wastewater. Different physico-chemical characteristics of these oxides make them more or less favourable for oxidative reactions. From these features, surface area, pore size/ volume and the crystalline structure have principal effects on their activities (Huang et al., 2001; Xue et al., 2009a). Moreover, because the rate constant of Equation (1) is much higher than Equation (2) $\left(63 \mathrm{M}^{-1} \mathrm{~s}^{-1}\right.$ vs. $\left.0.002-0.01 \mathrm{M}^{-1} \mathrm{~s}^{-1}\right)$, structural $\mathrm{Fe}^{\mathrm{II}}$ content is influential in Fenton oxidation systems (Xue et al., 2009a). These solid catalysts present powerful potential for degradation of recalcitrant pollutants such as dyes and phenolic compounds (Table 1).

Magnetite is a spinel iron oxide with chemical formula of $\left(\mathrm{Fe}^{3+}\right)_{\text {tet }}\left[\mathrm{Fe}^{2+} \mathrm{Fe}^{3+}\right]_{\mathrm{oct}} \mathrm{O}_{4}$ where $\mathrm{Fe}^{3+}$ cations occupy equally both octahedral and tetrahedral sites and $\mathrm{Fe}^{2+}$ cations are placed only in octahedral sites. In Fenton process, magnetite has gained considerable attention than other iron oxides due to its unique characteristics: (i) It is the only most abundant iron oxide with $\mathrm{Fe}^{\mathrm{II}}$ in its structure that improves hydroxyl radical production through Fenton reaction, Eq. (1) (Kwan and Voelker, 2003; Moura et al., 2005), (ii) The presence of octahedral sites in its structure that are mostly at the surface of the crystal and the catalytic activity is chiefly on account of the octahedral cations (Ramankutty and Sugunan, 2001), (iii) The magnetically easy separation of magnetite catalysts from the reaction system as a result of its magnetic property (Ai et al., 2011; Chun et al., 2012), (iv) Production of more active systems by modification in the physico-chemical properties of the magnetite through isostructural substitution of iron by different transition metals (Moura et al., 2005) and (v) Higher dissolution rate of magnetite compared to other iron oxides (Matta et al., 2008) and accordingly, higher electron mobility in its spinel structure (Litter and Blesa, 1992). As a consequence, magnetite has been used frequently in contaminant oxidation systems (Ai et al., 2011; Usman et al., 2012b; Xue et al., 2009a; Yang et al., 2009a; Zhong et al., 2012). Usman et al. (2012a) conducted six set of oxidative degradation systems using soluble $\mathrm{Fe}^{2+}$ with $\mathrm{H}_{2} \mathrm{O}_{2}$ (homogeneous Fenton), $\mathrm{H}_{2} \mathrm{O}_{2}$ and magnetite rich sand (heterogeneous Fenton-like), singular $\mathrm{H}_{2} \mathrm{O}_{2}$, magnetite and sodium persulfate, soluble $\mathrm{Fe}^{2+}$ and sodium persulfate and singular sodium persulfate to evaluate the efficacy of magnetite catalysed oxidation system to other combinations in degradation of oil hydrocarbons. The resulted degradation was above $80 \%$ by magnetite with both oxidants, ending to inconsiderable by-products, while the oxidants represented minor degradation efficiency exclusively or even with homogeneous catalyst (10-15\%).

The investigation to compare catalytic activity of amorphous iron (III) oxide, maghemite, magnetite and goethite mixed with quartz was carried out by Hanna et al. (2008) for methyl red degradation in presence of $\mathrm{H}_{2} \mathrm{O}_{2}$. The authors believed that the oxidation state of iron in the oxides has been the key parameter as $\mathrm{Fe}^{\mathrm{II}}$ is superior to $\mathrm{Fe}^{\mathrm{III}}$ in Fenton processes. In the study reported by Hanna et al. (2008), magnetite exhibited the highest rate constant normalised to surface area per unit mass of oxide (SSA) at neutral $\mathrm{pH}$ value and the rate constant according to pseudo-first order kinetic model for goethite was the highest at pH 5 . However, their 
Table 1

Iron oxides in Fenton reactions for removal of recalcitrant organic compounds.

\begin{tabular}{|c|c|c|c|c|c|c|c|c|c|}
\hline \multirow[t]{2}{*}{ Compound } & \multirow[t]{2}{*}{ Catalyst } & \multicolumn{6}{|c|}{ Operational condition } & \multirow[t]{2}{*}{ Optimal performance } & \multirow[t]{2}{*}{ References } \\
\hline & & {$\left[\mathrm{H}_{2} \mathrm{O}_{2}\right]$} & [Cat] & {$[\mathrm{OX}]$} & $\mathrm{pH}$ & $\mathrm{T}^{\circ} \mathrm{C}$ & $\lambda \mathrm{nm}$ & & \\
\hline Phenol (0.1 mM) & $\begin{array}{l}\text { Magnetite/mesocellular } \\
\text { carbon foam }\left(\mathrm{Fe}_{3} \mathrm{O}_{4} /\right. \\
\text { MSU-F-C) }\end{array}$ & $0.1 \mathrm{mM}$ & $0.1 \mathrm{~g} \mathrm{~L}^{-1}$ & - & 3.0 & 25 & - & $\begin{array}{l}95 \% \text { phenol degradation within } \\
4 \mathrm{~h} .\end{array}$ & $\begin{array}{l}\text { (Chun et al., } \\
\text { 2012) }\end{array}$ \\
\hline Bisphenol A [BPA] $0.01 \mathrm{mM}$ & Magnetite/oxalic acid & $0.5 \mathrm{mM}$ & $0.15 \mathrm{~g} \mathrm{~L}^{-1}$ & $0.2 \mathrm{mM}$ & 3.0 & $23-25$ & - & $\begin{array}{l}\text { Complete removal of BPA } \\
\text { within }<120 \text { min with half-life } \\
\text { of } \geq 15 \text { min. }\end{array}$ & $\begin{array}{l}\text { (Rodríguez } \\
\text { et al., } \\
\text { 2009a) }\end{array}$ \\
\hline Phenol $\left(0.2 \mathrm{~g} \mathrm{~L}^{-1}\right)$ & $\begin{array}{l}\text { Maghemite/ } \\
\text { MCM-14 (MSFM) }\end{array}$ & $0.98 \mathrm{mM}$ & $5 \mathrm{~g} \mathrm{~L}^{-1}$ & - & 4.0 & 40 & - & $\begin{array}{l}\text { TOC removal of } 78 \% \text { within } 2 \mathrm{~h} \text {, } \\
\text { decrease in TOC removal to } 65 \% \\
\text { after } 3 \text { times recycle reaction. }\end{array}$ & $\begin{array}{l}\text { (Xia et al., } \\
\text { 2011) }\end{array}$ \\
\hline Methyl red [MR] $50 \mu \mathrm{M}$ & $\begin{array}{l}\text { Quartz/amorphous } \\
\text { iron(III) oxide }\left(\mathrm{Q}_{1}\right) \text {, } \\
\text { quartz/maghemite }\left(\mathrm{Q}_{2}\right) \text {, } \\
\text { quartz/magnetite }\left(\mathrm{Q}_{3}\right) \\
\text { quartz/goethite }\left(\mathrm{Q}_{4}\right)\end{array}$ & $\mathrm{H}_{2} \mathrm{O}_{2} / \mathrm{Fe}: 20$ & - & - & $\begin{array}{l}5.0 \& \\
7.0\end{array}$ & 20 & - & $\begin{array}{l}\text { Higher oxidation of MR at } \mathrm{pH} \\
5.0 \text { than } 7.0 \text {, } 99 \% \text { MR sorption } \\
\text { on catalyst surface within } 2 \mathrm{~h} \text {, } \\
\text { highest degradation rate for } \mathrm{Q}_{4} \\
\left(\mathrm{~min}^{-1}\right) \text { at both pH values. }\end{array}$ & $\begin{array}{l}\text { (Hanna } \\
\text { et al., 2008) }\end{array}$ \\
\hline $\begin{array}{l}\text { Methylene blue [MB] } \\
\qquad 100 \mathrm{mg} \mathrm{L}^{-1}(10 \mathrm{~mL})\end{array}$ & $\begin{array}{l}\text { Niobia/iron oxide } \\
\text { composite }\end{array}$ & $2 \mathrm{~mL} / 10 \mathrm{~mL}$ & $30 \mathrm{mg}$ & - & & 25 & - & $\begin{array}{l}\text { } 90 \% \text { discoloration using } \\
\text { niobia:iron oxide } 1: 1,50 \% \\
\text { discoloration by niobia:iron } \\
\text { oxide } 1: 5 \text { within } 120 \text { min. }\end{array}$ & $\begin{array}{l}\text { (Oliveira } \\
\text { et al., 2007) }\end{array}$ \\
\hline $\begin{array}{l}\text { Quinolone [Q] } 10 \mathrm{mg} \mathrm{L}^{-1} \\
\quad(9.9 \mathrm{~mL})\end{array}$ & $\mathrm{Cu}^{2+} /$ goethite & - & $10 \mathrm{mg}$ & - & - & & - & $\begin{array}{l}\text { Q degradation within } 240 \mathrm{~min} \\
\text { via successive hydroxylations. } \\
\text { Higher degradation rate } \\
\text { compared to pure goethite. }\end{array}$ & $\begin{array}{l}\text { (Guimaraes } \\
\text { et al., 2009) }\end{array}$ \\
\hline $\begin{array}{l}\text { 2-chlorophenol }\left[\mathrm{H}_{2} \mathrm{O}_{2}\right] /[2 \text { - } \\
\text { CP] 30-50 }\end{array}$ & Goethite & - & $0.5 \mathrm{~g} \mathrm{~L}^{-1}$ & - & 3.0 & 50 & - & $\begin{array}{l}2-\mathrm{CP} \text { and TOC removal of } 99 \% \\
\text { and } 75 \% \text { respectively within } 6 \mathrm{~h} \text {. }\end{array}$ & $\begin{array}{l}\text { (Ortiz de la } \\
\text { Plata et al., } \\
2008 \text { ) }\end{array}$ \\
\hline $\begin{array}{l}\text { Pentachlorophenol, [PCP] } \\
0.0375 \mathrm{mM}\end{array}$ & Goethite and hematite & - & $0.4 \mathrm{~g} \mathrm{~L}^{-1}$ & $1.2 \mathrm{mM}$ & - & - & $<370$ & $\begin{array}{l}68 \% \text { PCP degradation in the } \\
\text { hematite suspension and } 83 \% \text { in } \\
\text { the goethite suspension within } \\
1 \mathrm{~h} \text {, minor PCP degradation } \\
\text { under UV light and without } \\
\text { oxalic acid, }\end{array}$ & $\begin{array}{l}\text { (Lan et al., } \\
\text { 2010) }\end{array}$ \\
\hline $\begin{array}{l}\text { Pharmaceuticals [pharma] } \\
\qquad 420 \mathrm{~mL} \text {, each } 10 \mathrm{mg} \mathrm{L}^{-1} \\
\text { [TOC] } 42 \mathrm{mg} \mathrm{L}^{-1}\end{array}$ & Immobilised goethite & $\begin{array}{l}\mathrm{H}_{2} \mathrm{O}_{2} / \mathrm{TOC}: \\
5.8-2.9\end{array}$ & $0.05 \mathrm{~g} \mathrm{~L}^{-1}$ & - & 3.0 & $25 \pm 2$ & - & $\begin{array}{l}100 \% \text { degradation of the } \\
\text { selected pharmaceuticals } \\
\text { within } 6 \mathrm{~h}, 12.5 \% \text { and } 21 \% \text { TOC } \\
\text { removal using } \mathrm{H}_{2} \mathrm{O}_{2} / \text { TOC mass } \\
\text { ratio of } 2.9 \text { and } 5.8 \text { respectively }\end{array}$ & $\begin{array}{l}\text { (Molina } \\
\text { et al., 2012) }\end{array}$ \\
\hline $\begin{array}{l}\text { 2,4,6-trinitrotoluene [TNT] } \\
0.11 \mathrm{mM}\end{array}$ & $\begin{array}{l}\text { Hematite, ferrihydrite, } \\
\text { lepidocrocite, goethite, } \\
\text { Magnetite, pyrite, green } \\
\text { rust }\end{array}$ & $3 \%(\mathrm{w} / \mathrm{v})$ & $2 \mathrm{~g} \mathrm{~L}^{-1}$ & - & 7 & - & - & $\begin{array}{l}60 \% \text { TNT removal with green } \\
\text { rust ( } 38.9 \% \text { Fe II) followed by } \\
\text { pyrite ( } 46.6 \% \text { Fe II) and } \\
\text { magnetite ( } 24.2 \% \text { Fe II), very } \\
\text { low TNT removal with } \\
\text { ferrihydrite, lepidocrocite and } \\
\text { hematite (Fe III bearing } \\
\text { minerals). }\end{array}$ & $\begin{array}{l}\text { (Matta } \\
\text { et al., 2008) }\end{array}$ \\
\hline $\begin{array}{l}\text { 2,4,6-trinitrotoluene [TNT] } \\
\text { 0.11 mM }\end{array}$ & $\begin{array}{l}\text { Magnetite } \\
\text { [EDTA] } 10 \mathrm{mM} \\
\text { [CMCD] } 5 \mathrm{mM} \text {, }\end{array}$ & $3 \%(\mathrm{w} / \mathrm{v})$ & $5 \%(w / w)$ & - & 7 & - & - & $\begin{array}{l}25 \% \text { TNT removal by magnetite } \\
\text { without chelating agent, } \\
\text { improved degradation up to } \\
50 \% \text { and } 62 \% \text { with EDTA and } \\
\text { CMCD respectively }\end{array}$ & $\begin{array}{l}\text { (Matta } \\
\text { et al., 2008) }\end{array}$ \\
\hline $\begin{array}{l}\text { Sulfadiazine [SD] } 20 \mathrm{mg} \mathrm{L}^{-1} \\
\quad(250 \mathrm{~mL})\end{array}$ & Goethite & $0.5 \mathrm{mM}$ & $0.4 \mathrm{~g} \mathrm{~L}^{-1}$ & $4.0 \mathrm{mM}$ & 3.5 & 30 & 350 & $\begin{array}{l}3 \%, 15 \% \text { and } 93 \% \text { SD removal via } \\
\text { UV, UV/goethite, UV/goethite/ } \\
\text { oxalate systems respectively } \\
\text { after } 40 \text { min of irradiation. }\end{array}$ & $\begin{array}{l}\text { (Wang } \\
\text { et al., 2010) }\end{array}$ \\
\hline 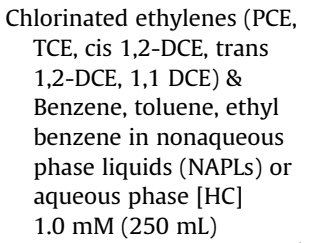 & $\begin{array}{l}\text { Goethite }(\alpha \text {-FeOOH }) \\
{[\mathrm{HC}] 1.0 \mathrm{mM}(250 \mathrm{~mL})}\end{array}$ & $0.01 \& 0.5 \%$ & $\begin{array}{l}0.22 \mathrm{~g} \sim 4 \mathrm{~g} \mathrm{~L}^{-1} \\
\mathrm{Fe}\end{array}$ & $4.0 \mathrm{mM}$ & 3.5 & $25 \pm 3$ & - & $\begin{array}{l}\text { Removal \% of ethyl } \\
\text { benzene }>\text { toluene }>\text { Benzene, } \\
\text { Lower removal percentage for } \\
\text { compounds with higher water } \\
\text { solubility. }\end{array}$ & $\begin{array}{l}\text { (Yeh et al., } \\
\text { 2008) }\end{array}$ \\
\hline Benzoic acids [BA] $50 \mathrm{mg} \mathrm{L}^{-1}$ & Hematite-SBA-15 & $162 \mathrm{mg} \mathrm{L}^{-1}$ & $0.6 \mathrm{~g} \mathrm{~L}^{-1}$ & - & 3.1 & $27 \pm 3$ & 365 & $\begin{array}{l}100 \% \text { BA removal and } 87.9 \% \\
\text { COD removal after } 240 \text { min, } 93 \% \\
\mathrm{H}_{2} \mathrm{O}_{2} \text { consumption, Efficiency } \\
\text { COD } \\
0.66 \text { abatement } / \mathrm{H}_{2} \mathrm{O}_{2 \text { consumed }} \text { of } \\
\end{array}$ & $\begin{array}{l}\text { (Pariente } \\
\text { et al., 2008) }\end{array}$ \\
\hline
\end{tabular}

performance in Fenton-like oxidation and also for adsorption of selected dye was pH-dependent, being higher at pH 5 than at 7.

In many instances, magnetite offered better performance. This might be due to the presence of $\mathrm{Fe}^{\mathrm{II}}$ cations in its structure (Matta et al., 2008). Nevertheless, the higher $\mathrm{Fe}^{\mathrm{II}}$ content than stoichiometric ratio in nano-sized magnetite could not increase phenol degradation considerably. The produced catalyst just expedited decomposition of $\mathrm{H}_{2} \mathrm{O}_{2}$ in non-productive manner that could be resulted from the $\cdot \mathrm{OH}$ radical scavenging by the surface of nanoparticle agglomerates of magnetite (Rusevova et al., 2012). 
Table 2

the preparation methods and characteristics of transition metal-substituted iron oxide catalysts.

\begin{tabular}{|c|c|c|c|c|c|c|}
\hline \multirow[t]{2}{*}{ Heterogeneous Catalyst } & \multicolumn{4}{|l|}{ Characteristics } & \multirow[t]{2}{*}{ Preparation method } & \multirow[t]{2}{*}{ References } \\
\hline & Occupancy & $\begin{array}{l}\text { BET surface } \\
\text { area }\end{array}$ & Particle size & Pore diameter & & \\
\hline $\begin{array}{l}\mathrm{Fe}_{3-x} \mathrm{Cr}_{x} \mathrm{O}_{4}(x=0.00,0.07,0.26 \\
\quad 0.42 \text { and } 0.51) \\
\mathrm{Fe}_{3} \mathrm{O}_{4} \\
\mathrm{Fe}_{2.93} \mathrm{Cr}_{0.07} \mathrm{O}_{4} \\
\mathrm{Fe}_{2.74} \mathrm{Cr}_{0.26} \mathrm{O}_{4} \\
\mathrm{Fe}_{2.58} \mathrm{Cr}_{0.42} \mathrm{O}_{4} \\
\mathrm{Fe}_{2.49} \mathrm{Cr}_{0.51} \mathrm{O}_{4}\end{array}$ & $\begin{array}{l}\text { Replacing of } \mathrm{Cr}^{3+} \\
\text { by } \mathrm{Fe}^{3+} \text { oct and for } \\
\text { higher } \mathrm{Cr} \text { contents } \\
\text { by } \mathrm{Fe}^{2+} \text { oct and } \\
\mathrm{Fe}^{3+} \text { tet }\end{array}$ & $\begin{array}{l}\text { Significant } \\
\text { increase }\end{array}$ & - & $\begin{array}{l}\text { Decrease from } \\
\text { meso- to micropore }\end{array}$ & $\begin{array}{l}\text { Conventional co- } \\
\text { precipitation method }\end{array}$ & $\begin{array}{l}\text { (Magalhães et al., } \\
\text { 2007) }\end{array}$ \\
\hline $\begin{array}{l}\mathrm{Fe}_{3-x} \mathrm{Ti}_{x} \mathrm{O}_{4}(x=0.00,0.20,0.46,0.71 \\
\quad \text { and } 0.98) \\
\mathrm{Fe}_{3} \mathrm{O}_{4} \\
\mathrm{Fe}_{2.80} \mathrm{Ti}_{0.20} \mathrm{O}_{4} \\
\mathrm{Fe}_{2.54} \mathrm{Ti}_{0.46} \mathrm{O}_{4} \\
\mathrm{Fe}_{2.29} \mathrm{Ti}_{0.71} \mathrm{O}_{4} \\
\mathrm{Fe}_{2.02} \mathrm{Ti}_{0.98} \mathrm{O}_{4}\end{array}$ & Octahedral sites & $\begin{array}{l}\text { Significant } \\
\text { increase }\end{array}$ & $\begin{array}{l}\text { Decrease } \\
(\approx 82 \mathrm{~nm})\end{array}$ & Decrease & $\begin{array}{l}\text { Precipitation-oxidation } \\
\text { method }\end{array}$ & (Zhong et al., 2012) \\
\hline $\begin{array}{l}\mathrm{Fe}_{3-x} \mathrm{Mn}_{x} \mathrm{O}_{4}(x=0.21,0.26 \text { and } \\
\quad 0.53) \\
\mathrm{Fe}_{3} \mathrm{O}_{4} \\
\mathrm{Fe}_{2.79} \mathrm{Mn}_{0.21} \mathrm{O}_{4} \\
\mathrm{Fe}_{2.74} \mathrm{Mn}_{0.26} \mathrm{O}_{4} \\
\mathrm{Fe}_{2.47} \mathrm{Mn}_{0.53} \mathrm{O}_{4}\end{array}$ & $\begin{array}{l}\text { Replacing } \mathrm{Fe}^{2+} \text { in } \\
\text { the octahedral site }\end{array}$ & - & - & - & $\begin{array}{l}\text { Co-precipitation of the } \\
\text { precursor ferric } \\
\text { hydroxyl-acetate } \\
\text { containing the metals } \\
\text { Mn }\end{array}$ & $\begin{array}{l}\text { (Costa et al., 2003; } \\
\text { Costa et al., 2006; } \\
\text { Oliveira et al., 2000) }\end{array}$ \\
\hline $\begin{array}{l}\mathrm{Fe}_{3-\mathrm{x}} \mathrm{Co}_{\mathrm{x}} \mathrm{O}_{4}(x=0 ; 0.19 ; 0.38 \text { and } \\
\quad 0.75) \\
\mathrm{Fe}_{3} \mathrm{O}_{4} \\
\mathrm{Fe}_{2.81} \mathrm{Co}_{0.19} \mathrm{O}_{4} \\
\mathrm{Fe}_{2.62} \mathrm{Co}_{0.38} \mathrm{O}_{4} \\
\mathrm{Fe}_{2.25} \mathrm{Co}_{0.75} \mathrm{O}_{4}\end{array}$ & $\begin{array}{l}\text { Replacing } \mathrm{Fe}^{2+} \text { in } \\
\text { the octahedral site }\end{array}$ & - & - & - & $\begin{array}{l}\text { Co-precipitation of the } \\
\text { precursor ferric } \\
\text { hydroxyl-acetate } \\
\text { containing the metals } \\
\text { Co }\end{array}$ & $\begin{array}{l}\text { (Costa et al., 2003; } \\
\text { Costa et al., 2006; } \\
\text { Lelis et al., 2004) }\end{array}$ \\
\hline $\begin{array}{l}\mathrm{Fe}_{3-\mathrm{x}} \mathrm{Ni}_{\mathrm{x}} \mathrm{O}_{4} \\
(x=0 ; 0.10 ; 0.28 \text { and } 0.54) \\
\mathrm{Fe}_{3} \mathrm{O}_{4} \\
\mathrm{Fe}_{2.90} \mathrm{Ni}_{0.10} \mathrm{O}_{4} \\
\mathrm{Fe}_{2.72} \mathrm{Ni}_{0.28} \mathrm{O}_{4} \\
\mathrm{Fe}_{2.46} \mathrm{Ni}_{0.54} \mathrm{O}_{4}\end{array}$ & $\begin{array}{l}\text { Replacing } \mathrm{Fe}^{2+} \text { in } \\
\text { the octahedral site }\end{array}$ & - & - & - & $\begin{array}{l}\text { Co-precipitation of the } \\
\text { precursor ferric } \\
\text { hydroxyl-acetate } \\
\text { Containing the metals } \\
\mathrm{Ni}\end{array}$ & $\begin{array}{l}\text { (Costa et al., 2003; } \\
\text { Costa et al., 2006) }\end{array}$ \\
\hline $\begin{array}{l}\mathrm{Fe}_{3-\mathrm{x}-\mathrm{x}^{\prime}} \mathrm{Ti}_{\mathrm{x}} \mathrm{V}_{\mathrm{x}^{\prime}} \mathrm{O}_{4}(x=0.00,0.40 \\
\quad 0.42,0.54 \text { and } 0.69) \\
\left(x^{\prime}=0.00,0.03,0.08,0.13 \text { and } 0.32\right) \\
\mathrm{Fe}_{3} \mathrm{O}_{4} \\
\mathrm{Fe}_{2.31} \mathrm{Ti}_{0.69} \mathrm{O}_{4} \\
\mathrm{Fe}_{2.43} \mathrm{Ti}_{0.54} \mathrm{~V}_{0.03} \mathrm{O}_{4} \\
\mathrm{Fe}_{2.50} \mathrm{Ti}_{0.42} \mathrm{~V}_{0.08} \mathrm{O}_{4} \\
\mathrm{Fe}_{2.47} \mathrm{Ti}_{0.40} \mathrm{~V}_{0.13} \mathrm{O}_{4} \\
\mathrm{Fe}_{2.68} \mathrm{~V}_{0.32} \mathrm{O}_{4}\end{array}$ & Octahedral site & Increase & $\begin{array}{l}\text { Decrease } \\
(<100 \mathrm{~nm})\end{array}$ & - & $\begin{array}{l}\text { Co-precipitation } \\
\text { method }\end{array}$ & (Liang et al., 2012) \\
\hline $\begin{array}{l}\mathrm{Fe}_{3-x} \mathrm{Ti}_{x} \mathrm{O}_{4}(x=0.00,0.17,0.23 \\
\quad 0.37,0.50,0.78) \\
\mathrm{Fe}_{3} \mathrm{O}_{4} \\
\mathrm{Fe}_{2.83} \mathrm{Ti}_{0.17} \mathrm{O}_{4} \\
\mathrm{Fe}_{2.77} \mathrm{Ti}_{0.23} \mathrm{O}_{4} \\
\mathrm{Fe}_{2.63} \mathrm{Ti}_{0.37} \mathrm{O}_{4} \\
\mathrm{Fe}_{2.50} \mathrm{Ti}_{0.50} \mathrm{O}_{4} \\
\mathrm{Fe}_{2.22} \mathrm{Ti}_{0.78} \mathrm{O}_{4}\end{array}$ & $\begin{array}{l}\text { Replacing } \mathrm{Fe}^{3+} \text { in } \\
\text { the octahedral site }\end{array}$ & $\begin{array}{l}\text { Significant } \\
\text { increase from } \\
6.65 \mathrm{~m}^{2} \mathrm{~g}^{-1} \\
-20.7 \mathrm{~m}^{2} \mathrm{~g}^{-1}\end{array}$ & - & - & $\begin{array}{l}\text { New soft chemical } \\
\text { method }\end{array}$ & $\begin{array}{l}\text { (Yang et al., 2009a; } \\
\text { Yang et al., 2009b) }\end{array}$ \\
\hline $\begin{array}{l}\mathrm{Fe}_{3-x} \mathrm{~V}_{x} \mathrm{O}_{4}(x=0.00,0.16,0.26 \\
\quad 0.34) \\
\mathrm{Fe}^{2+}{ }_{0.61} \mathrm{Fe}^{3+}{ }_{2.39} \mathrm{O}_{4} \\
\mathrm{Fe}^{2+}{ }_{0.45} \mathrm{Fe}^{3+}{ }_{2.39} \mathrm{~V}_{0.16} \mathrm{O}_{4} \\
\mathrm{Fe}^{2+}{ }_{0.70} \mathrm{Fe}^{3+}{ }_{2.04} \mathrm{~V}_{0.26} \mathrm{O}_{4} \\
\mathrm{Fe}^{2+}{ }_{0.73} \mathrm{Fe}^{3+}{ }_{1.93} \mathrm{~V}_{0.34} \mathrm{O}_{4}\end{array}$ & $\begin{array}{l}\text { Replacing } \mathrm{Fe}^{3+} \text { in } \\
\text { the octahedral site }\end{array}$ & $\begin{array}{l}\text { No obvious } \\
\text { change }\end{array}$ & $\begin{array}{l}\text { No obvious } \\
\text { change }\end{array}$ & 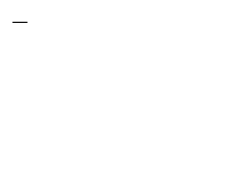 & $\begin{array}{l}\text { Precipitation } \\
\text {-oxidation method }\end{array}$ & (Liang et al., 2010) \\
\hline $\begin{array}{l}\mathrm{Fe}_{3-x} \mathrm{Al}_{x} \mathrm{O}_{4}(x=0.00,1.48,2.14 \\
\quad 5.49,8.07 \mathrm{~mol} \%)\end{array}$ & Replacing $\mathrm{Fe}^{3+}$ & $\begin{array}{l}\text { No obvious } \\
\text { change }\end{array}$ & Decrease & No obvious change & $\begin{array}{l}\text { Co-precipitation } \\
\text { method }\end{array}$ & $\begin{array}{l}\text { (Jentzsch et al., } \\
\text { 2007) }\end{array}$ \\
\hline $\begin{array}{l}\mathrm{Fe}_{3} \mathrm{O}_{4} \\
\mathrm{Fe}_{2.83} \mathrm{Al}_{0.17} \mathrm{O}_{4} \\
\mathrm{Fe}_{2.77} \mathrm{Al}_{0.23} \mathrm{O}_{4} \\
\mathrm{Fe}_{2.63} \mathrm{Al}_{0.37} \mathrm{O}_{4} \\
\mathrm{Fe}_{2.50} \mathrm{Al}_{0.50} \mathrm{O}_{4}\end{array}$ & & & & & & \\
\hline $\begin{array}{l}\mathrm{Cu}_{\mathrm{x}} \mathrm{Fe}_{3-\mathrm{x}} \mathrm{O}_{4}(x=0.00,0.2,0.3) \\
\mathrm{Fe}_{3} \mathrm{O}_{4} \\
\mathrm{Cu}_{0.2} \mathrm{Fe}_{2.8} \mathrm{O}_{4} \\
\mathrm{Cu}_{0.3} \mathrm{Fe}_{2.7} \mathrm{O}_{4}\end{array}$ & - & - & - & - & Mechanical alloying & (Lee and Joe, 2010) \\
\hline $\begin{aligned} \mathrm{Fe}_{2-x} \mathrm{Nb}_{x} \mathrm{O}_{3}(\% \mathrm{Nb}=0.00,1.49 \\
5.00,9.24) \\
\% \mathrm{Nb}=0.00 \text { pure } \mathrm{Hm} \\
\% \mathrm{Nb}=1.49: \mathrm{Hm}-\mathrm{Nb} 2 \\
\% \mathrm{Nb}=5.00: \mathrm{Hm}-\mathrm{Nb} 5 \\
\% \mathrm{Nb}=9.24: \mathrm{Hm}-\mathrm{Nb} 10\end{aligned}$ & Replacing $\mathrm{Fe}^{3+}$ & Increase & Decrease & - & $\begin{array}{l}\text { Conventional co- } \\
\text { precipitation method }\end{array}$ & (Silva et al., 2009) \\
\hline
\end{tabular}


Table 2 (continued)

\begin{tabular}{|c|c|c|c|c|c|c|}
\hline \multirow[t]{2}{*}{ Heterogeneous Catalyst } & \multicolumn{4}{|l|}{ Characteristics } & \multirow[t]{2}{*}{ Preparation method } & \multirow[t]{2}{*}{ References } \\
\hline & Occupancy & $\begin{array}{l}\text { BET surface } \\
\text { area }\end{array}$ & Particle size & Pore diameter & & \\
\hline $\begin{array}{l}\text { Nb-hematite-maghemite }(\alpha- \\
\left.\mathrm{Fe}_{2} \mathrm{O}_{3}\right)-\left(\gamma-\mathrm{Fe}_{2} \mathrm{O}_{3}\right)-\mathrm{FeNb}_{2} \mathrm{O}_{6} \\
\mathrm{Nb}-\mathrm{NCBT} \text { : } \mathrm{Nb} \text { - nanocomposite } \\
\text { before } \mathrm{H}_{2} \mathrm{O}_{2} \text { treatment } \\
\text { Nb-NCAT: } \mathrm{Nb} \text { - nanocomposite } \\
\text { after } \mathrm{H}_{2} \mathrm{O}_{2} \text { treatment }\end{array}$ & Replacing $\mathrm{Fe}^{3+}$ & & Decrease & - & $\begin{array}{l}\text { Co-precipitation } \\
\text { method }\end{array}$ & (Silva et al., 2011) \\
\hline $\begin{array}{l}\mathrm{Si}-\mathrm{FeOOH} \\
\mathrm{Si} / \mathrm{Fe}(0.0,0.1,0.2,0.33)\end{array}$ & $\begin{array}{l}\mathrm{Fe}-\mathrm{Si} \text { complex } \\
\text { formation }\end{array}$ & Increase & Decrease & - & Not mentioned & (Yuan et al., 2011) \\
\hline $\begin{array}{l}\text { Nb-goethite } \\
\% \mathrm{Nb}=4,7 \& 11) \\
\% \mathrm{Nb}=0.00 \text { pure } \mathrm{Gt} \\
\% \mathrm{Nb}=4.0: \mathrm{Hm}-\mathrm{Nb} 4 \\
\% \mathrm{Nb}=7.00: \mathrm{Hm}-\mathrm{Nb} 7 \\
\% \mathrm{Nb}=11.0: \mathrm{Hm}-\mathrm{Nb} 11\end{array}$ & Replacing $\mathrm{Fe}^{3+}$ & Increase & - & Increase & $\begin{array}{l}\text { Co-precipitation } \\
\text { followed by thermal } \\
\text { treatment at } 60{ }^{\circ} \mathrm{C} \\
(72 \mathrm{~h})\end{array}$ & $\begin{array}{l}\text { (Oliveira et al., } \\
\text { 2008) }\end{array}$ \\
\hline $\begin{array}{l}\mathrm{Fe}_{1-x} \mathrm{Ni}_{x} \mathrm{OOH} \\
\% \mathrm{Ni}(0.1-10)\end{array}$ & Replacing $\mathrm{Fe}^{3+}$ & Increase & - & Increase & $\begin{array}{l}\text { Co-precipitation } \\
\text { followed by thermal } \\
\text { treatment at } 60{ }^{\circ} \mathrm{C} \text { for } \\
72 \mathrm{~h}\end{array}$ & $\begin{array}{l}\text { (de Souza et al., } \\
\text { 2010) }\end{array}$ \\
\hline
\end{tabular}

Goethite, an iron oxyhydroxide mineral with chemical formula of $\alpha-\mathrm{Fe}^{\mathrm{III}} \mathrm{O}(\mathrm{OH})$, is another commonly used iron oxide among $\mathrm{Fe}^{\mathrm{III}}$ bearing minerals for catalytic Fenton degradation/photodegradation of organic pollutants (Hanna et al., 2008; Wang et al., 2010) due to its (i) ability to operate in a wide range of $\mathrm{pH}$, (ii) positive performance with sun light (iii) higher stability thermodynamically and (iv) being relatively low priced and environmentally friendly (Ortiz de la Plata et al., 2008). In an investigation, the results for half-lives $\left(t_{1 / 2}\right)$ of photodegraded sulfadiazine which is the time required for degradation of $50 \%$ of initial sulfadiazine concentration, for various studied iron oxides exhibited the following order: hematite $\left(\alpha-\mathrm{Fe}_{2} \mathrm{O}_{3}\right)>$ maghemite $(\gamma$ $\left.\mathrm{Fe}_{2} \mathrm{O}_{3}\right)>$ lepidocrocite $(\gamma$-FeOOH$)>$ goethite $(\alpha$-FeOOH) (Wang et al., 2010) that shows better catalytic performance of goethite.

Despite the fact that iron oxides provide acceptable scores for contaminant degradation in Fenton-like reactions with uncontrolled $\mathrm{pH}$ values, several works have been put in practice to improve their efficiency and increase decomposition rate of probe molecules through some modifications in their structure. Thermal treatment of catalyst surface under $\mathrm{H}_{2}$ atmosphere, for example, resulted in generation of $\mathrm{Fe}^{\mathrm{II}}$ sites on the goethite surface and wherefore, enhanced the goethite efficiency significantly in Fenton reaction for quinolone degradation (Guimarães et al., 2008). In their study, pure goethite $/ \mathrm{H}_{2} \mathrm{O}_{2}$ system did not perform similarly due to the presence of only $\mathrm{Fe}^{3+}$ ions on goethite surface and indicated that quinoline degradation occurred chiefly on $\mathrm{Fe}^{\mathrm{II}}$ sites through $\cdot \mathrm{OH}$ radical generation route.

Chelating agents (CAs), on the other side, can enhance degradation efficiency of iron minerals at near neutral pH (Xue et al., 2009b) via their positive effects on non-reductive/reductive dissolution rate of iron oxide (Wang et al., 2008). Xue et al. (2009b) investigated the effect of EDTA, carboxymethyl $\beta$-cyclodextrin $(\mathrm{CMCD})$, oxalate, tartrate, citrate and succinate as CAs with magnetite on pentachlorophenol (PCP) decomposition rate. All applied CAs promoted iron-oxide dissolution amount and PCP oxidation rate. In spite of strong chelating ability of EDTA and its highest oxidation rate compared to the other CAs in homogeneous Fenton system, it represented lower efficiency than oxalate in heterogeneous Fenton system due to its strong binding to magnetite surface. Similar results were obtained by Lan et al. (2010) where heterogeneous photodegradation, dechlorination and detoxification of PCP with goethite or hematite significantly bolstered up with $1.2 \mathrm{mM}$ of oxalate due to the formation of $\mathrm{Fe}^{\mathrm{III}}$ species $\left(\mathrm{Fe}\left(\mathrm{C}_{2} \mathrm{O}_{4}\right)_{3}^{3-}\right)$ and $\mathrm{Fe}^{\mathrm{II}}$ species $\left(\mathrm{Fe}\left(\mathrm{C}_{2} \mathrm{O}_{4}\right)_{2}^{-2}\right)$ with powerful photoactivity in both iron oxides suspensions. Interestingly, photodegradation of these complexes generated $1.0 \mathrm{mg} \mathrm{L}^{-1}$ and $2.4 \mathrm{mg} \mathrm{L}^{-1}$ hydrogen peroxide under the operational conditions of $\mathrm{pH} 3.5,\left[\mathrm{C}_{2} \mathrm{O}_{4}^{2-}\right] 1.2 \mathrm{mM}$ and $0.4 \mathrm{~g} \mathrm{~L}^{-1}$ catalyst within less than 10 min of reaction time in goethite and hematite systems that consequently, increased the PCP degradation through Fenton reaction. However, the oxalate concentrations above $1.2 \mathrm{mM}$ decreased the degradation rate as a consequence of $\cdot \mathrm{OH}$ ion scavenging by oxalate. Oxalate entrance to the UV/goethite system at $4.0 \mathrm{mM}$ also extremely promoted sulfadiazine $\left(20 \mathrm{mg} \mathrm{L}^{-1}\right)$ degradation from $15 \%$ to $93 \%$ in acidic medium (Wang et al., 2010). The oxalate concentrations of $>4.0 \mathrm{mM}$ contributed in occupancy of adsorption sites on the goethite surface and its contest for hydroxyl radicals. Accordingly, the amount of generated $\mathrm{H}_{2} \mathrm{O}_{2}$ was found to decrease due to the increase in the formation of $\mathrm{Fe}^{\mathrm{III}}$ species (Lei et al., 2006). In another study, the catalytic performance of magnetite was improved by adding CMCD (Matta et al., 2008). This combination elevated the degradation of 2,4,6-trinitrotoluene (TNT) three times more than only magnetite.

Another modification is to substitute the iron species of iron minerals with other active transition metals. Several challenges existed for implementation of transition metal substituted iron oxides (TMSIOs) in practice as heterogeneous catalysts due to the stability of active cations in their structure and relatively simple and inexpensive production methods reported for magnetite (Costa et al., 2003; Liang et al., 2013; Zhong et al., 2013) and goethite (Guimaraes et al., 2009; Oliveira et al., 2007).

\section{Transition metal substituted iron oxides}

Magnetite, goethite and hematite are well-known iron minerals that have been used in synthesis of TMSIOs. Iron in the magnetite structure can be substituted isomorphically by other transition metals. The most common preparation method is coprecipitation of highly pure predetermined amount of ferrous and selected transition metal salts under $\mathrm{N}_{2}$ atmosphere to avoid the oxidation of ferrous cations (Liang et al., 2012; Yang et al., 2009a) that could be followed by thermal treatment at 400$430{ }^{\circ} \mathrm{C}$ (Costa et al., 2003; Lelis et al., 2004). Yang et al. (2009a) presented the following set of reactions (Equations 3-6) involved in synthesis of $\mathrm{Fe}_{3-\chi} \mathrm{Ti}_{x} \mathrm{O}_{4}$ that were proposed by Sugimoto and Matijević (1980):

$(3-x) \mathrm{Fe}^{2+}+x \mathrm{Ti}^{4+}+(6+2 x) \mathrm{OH}^{-} \rightarrow \mathrm{Fe}_{3-x} \mathrm{Ti}_{x}(\mathrm{OH})_{6+2 x}$ 


$$
\begin{aligned}
& \mathrm{Fe}_{3-x} \mathrm{Ti}_{x}(\mathrm{OH})_{6+2 x}+(1-x) \mathrm{NO}_{3}^{-} \rightarrow \mathrm{Fe}_{3-x} \mathrm{Ti}_{x} \mathrm{O}_{4}+(1-x) \mathrm{NO}_{2}^{-} \\
& \quad+(3+x) \mathrm{H}_{2} \mathrm{O}
\end{aligned}
$$

$$
\begin{aligned}
& \mathrm{Fe}_{3-x} \mathrm{Ti}_{x}(\mathrm{OH})_{6+2 x}+(2-2 x) \mathrm{NO}_{2}^{-} \rightarrow \mathrm{Fe}_{3-x} \mathrm{Ti}_{x} \mathrm{O}_{4}+(2-2 x) \mathrm{NO} \\
& \quad+(2+2 x) \mathrm{H}_{2} \mathrm{O}+(2-2 x) \mathrm{OH}^{-}
\end{aligned}
$$

$5 \mathrm{Fe}_{3-x} \mathrm{Ti}_{x}(\mathrm{OH})_{6+2 x}+(2-2 x) \mathrm{NO} \rightarrow 5 \mathrm{Fe}_{3-x} \mathrm{Ti}_{x} \mathrm{O}_{4}+(2-2 x)$

$\mathrm{NH}_{3}+(8 x+12) \mathrm{H}_{2} \mathrm{O}$

TMSIOs of other iron oxides were often prepared under air atmosphere (Alvarez et al., 2006; dos Santos et al., 2001; Guimaraes et al., 2009) since they contain only Fe ${ }^{\mathrm{III}}$ species. Meanwhile, the type and the amount of loaded transition metal, preparation method and the range of temperature affect the characteristics of the produced TMSIO (Table 2). Development of several catalysts through the incorporation of transition metal/metals into the magnetite structure has been well-documented. A large number of studies have dealt with introduction of the transition metals of period 4 in periodic table such as Titanium (Liang et al., 2012; Yang et al., 2009a; Zhong et al., 2012), Vanadium (Liang et al., 2012, 2010), Chromium (Magalhães et al., 2007; Zhong et al., 2013), Manganese (Coker et al., 2008; Costa et al., 2003; Oliveira et al., 2000), Cobalt (Coker et al., 2008; Costa et al., 2003; Lelis et al., 2004), Nickel (Coker et al., 2008; Costa et al., 2003), Copper (Lee and Joe, 2010), Zinc (Coker et al., 2008) and other metals like Aluminium (Jentzsch et al., 2007) into the magnetite structure. Several other studies related to goethite, hematite or maghemite impregnated with Manganese (Alvarez et al., 2006; Krehula and Musić, 2006), Copper (Guimaraes et al., 2009), Nickel (Krehula et al., 2005), Zinc (Krehula et al., 2006), Niobium (Silva et al., 2009), Silicon (Yuan et al., 2011) and Gallium (dos Santos et al., 2001) or with metal oxides (Baldrian et al., 2006; Nie et al., 2009; Oliveira et al., 2007) also were carried out. Careful study of the recent investigations reported in the literature indicate that such catalysts can be considered as modern promising heterogeneous catalysts capable of activating Fenton oxidation of recalcitrant compounds with or without the illumination of UV-Vis light. Hence, in relation to TMSIOs, the main aspects that are important to be considered are the valence and occupied site, the physicochemical changes arising from the incorporation, the changes in adsorption capacity of the catalyst and its catalytic activity for the target organic contaminant removal (Liang et al., 2010).

\subsection{Valence and occupied sites}

In most TMSIOs, the structural iron species is replaced isomorphically with introduced cation. If so, the oxidation state of the imported transition metal is similar to the exchanged iron species or has one or two unit difference, in addition to having similar ionic radius. For instance, the substitution of octahedral $\mathrm{Fe}^{3+}$ by $\mathrm{Cr}^{3+}$ in $\mathrm{Fe}_{3-x} \mathrm{Cr}_{x} \mathrm{O}_{4}$ with similar ionic radius $(64.5 \mathrm{pm}$ vs. $61.5 \mathrm{pm})$ (Magalhães et al., 2007), $\mathrm{Fe}^{3+}$ by $\mathrm{Nb}^{5+}$ with the same ionic radius $(64 \mathrm{pm})$ (Oliveira et al., 2008), $\mathrm{Fe}^{2+}(78 \mathrm{pm})$ by $\mathrm{Co}^{2+}, \mathrm{Ni}^{2+}$ and $\mathrm{Mn}^{2+}$ (74.5, 69 and 83 pm respectively) (Costa et al., 2006) or $\mathrm{Fe}^{3+}$ by Ti ${ }^{4+}$

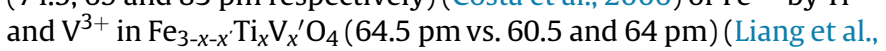
2012). Regarding those substitutions with unequal charges, as reported for $\mathrm{Ti}^{4+}$ (Zhong et al., 2012), $\mathrm{Fe}^{3+}$ replacement by $\mathrm{Ti}^{4+}$ has been responsible for the reduction of same amount of $\mathrm{Fe}^{3+}$ to $\mathrm{Fe}^{2+}$ on the basis of electrovalence equilibrium (Pearce et al., 2010). For the replacements in the absence of reduction, the structural dislocations would be adjusted by inducing oxygen vacancis (Moura et al., 2006) that is believed to be the active sites for hydroxyl radical generation in Fenton oxidation reactions. However, the presence of UV irradiation also simulates the generation of anion vacancies $\left(\mathrm{AV}^{*}\right)$ through the reduction of $\mathrm{Ti}^{4+}$ to $\mathrm{Ti}^{3+}$ (Equation (7)) (Zhong et al., 2012):

$2 \mathrm{Ti}^{4+}+\mathrm{O}^{2-}+h v \rightarrow 2 \mathrm{Ti}^{3+}+(1 / 2) \mathrm{O}_{2}+\mathrm{AV}^{*}$

In $\mathrm{Sn}-\mathrm{FeOOH}$, the tetravalent Sn cations occupied octahedral sites and the formation of cation vacancies helped to balance charge deficiency (Berry et al., 2000). The sextet in the Mössbauer spectra of goethite was altered to doublet by introduction of $\mathrm{Nb}$ to its structure (Oliveira et al., 2008) that is reported to be an evidence for the formation of oxygen vacancies in goethite structure (dos Santos et al., 2001).

As reported (Jacobs et al., 1994), the cations of octahedral sites are chiefly responsible for the catalytic activity and are about totally located on the surface of the crystal in the spinel structures. In TMSmagnetite, the imported cations are mostly located in octahedral sites (Costa et al., 2003; Liang et al., 2012; Zhong et al., 2012) and in tetrahedral sites only if the concentration of imported active cation was very high (Magalhães et al., 2007). In a study conducted by Lelis et al. (2004), the imported $\mathrm{Co}^{2+}$ cations occupied $\mathrm{Fe}^{2+}$ station not only at octahedral sites of magnetite spinel structure but also octahedral coordination sites. In other iron oxides, the incorporated transition metal replaced Fe ${ }^{\text {III }}$ cations (Silva et al., 2009, 2011). For non-metal incorporations, the ion forms a complex with structural iron as reported by Yuan et al. (2011) for Si-goethite.

\subsection{Physico-chemical changes}

The imported transition metal may bring about remarkable changes in iron oxide physico-chemical properties such as the increase in surface area (Magalhães et al., 2007) and/or a decrease in particle size in which are desirable for catalytic activities (Zhong et al., 2012, 2013). Table 2 gives data regarding the structural changes of various developed TMSIOs. The extent of the changes are found to be dependent on the preparation technique (Lee et al., 2008), type and the amount of the introduced metal (Magalhães et al., 2007) and the nature of the occupied site (Costa et al., 2003; Zhong et al., 2012). However, the main structural phase of the iron oxide such as the spinel structure of magnetite or hematite's hexagonal structure are often kept unchanged after the incorporation. On the other hand, the change in oxidation temperature could have resulted in magnetite transformation to maghemite or hematite respectively at $270^{\circ} \mathrm{C}$ and $600^{\circ} \mathrm{C}$ of which at $600{ }^{\circ} \mathrm{C}$ the substituted metal was ejected from the hexagonal structure of the produced hematite in the form of a separate phase, as summarised in Equations 8 and 9 (Magalhães et al., 2007):

$\mathrm{Fe}_{3-x} \mathrm{Cr}_{x} \mathrm{O}_{4}+\mathrm{O}_{2}\left(270^{\circ} \mathrm{C}\right) \rightarrow \mathrm{Fe}_{3-x} \mathrm{Cr}_{x} \mathrm{O}_{4+\delta}$ (maghemite)

$\mathrm{Fe}_{3-x} \mathrm{Cr}_{x} \mathrm{O}_{4+\delta}$ (maghemite) $\left(600^{\circ} \mathrm{C}\right) \rightarrow \alpha-\mathrm{Fe}_{2} \mathrm{O}_{3}$ (Hematite) $+\mathrm{Cr}-$ oxide

Although Magalhães et al. (2007) reported a remarkable decrease in the discoloration rate and TOC removal by the increment in the amount of introduced $\mathrm{Cr}$ from $\mathrm{Cr}_{0.07}$ to $\mathrm{Cr}_{0.51}$, higher content of $\mathrm{Cr}$ resulted in thermal stabilisation of the maghemite cubic structure. Oliveira et al. (2008) reported a rise the the oxidation temperature range for goethite to hematite transformation concurrent increasing in $\mathrm{Nb}$ content $\left(218{ }^{\circ} \mathrm{C}\right.$ to $251{ }^{\circ} \mathrm{C}$ and $271^{\circ} \mathrm{C}$ in $\mathrm{Nb} 7 \%$ and $\mathrm{Nb} 11 \%$ ). Similarly, $\mathrm{Nb}$-hematite reduction at $500{ }^{\circ} \mathrm{C}$ resulted in the formation of magnetite, but at higher temperatures, $\mathrm{Nb}$ was 
expelled from the structure; whereas the pure hematite reduced to metallic iron at $900{ }^{\circ} \mathrm{C}$ (Silva et al., 2009).

Frequent reports from the characterisation studies of this category of heterogeneous catalysts using Brunauer-Emmett-Teller (BET) surface area analysis represented a significant increase in surface area (de Souza et al., 2010; Magalhães et al., 2007; Zhong et al., 2012) that could be due to the decline in their particle size and/or pore diameter (Silva et al., 2009). For instance, $\mathrm{Fe}^{3+}$ substitution by $\mathrm{Cr}^{3+}$ in $\mathrm{Fe}_{3-x} \mathrm{Cr}_{x} \mathrm{O}_{4}$ decreased the pore diameter from meso to micro-size resulted in a significant increase in surface area (Magalhães et al., 2007). Furthermore, the values of surface area for pure hematite and $\mathrm{Fe}_{2-x} \mathrm{Nb}_{x} \mathrm{O}_{3}$ with \% $\mathrm{Nb}$ of $1.49,5.00$ and 9.24 were obtained respectively $11,17,34$ and $42 \mathrm{~m}^{2} \mathrm{~g}^{-1}$ (Silva et al., 2009) and in Nb-goethite, it changed from $70 \mathrm{~m}^{2} \mathrm{~g}^{-1}$ for pure goethite to 78 , 99, and $136 \mathrm{~m}^{2} \mathrm{~g}^{-1}$ in $\mathrm{Nb} 4 \%, \mathrm{Nb} 7 \%$ and Nb11\% (Oliveira et al., 2008). However, in non-transition metals, Jentzsch et al. (2007) reported an unclear change in the surface area and porosity of the Almagnetite particles.

Apart from the catalytic characteristics in most iron oxides, preserving the magnetic property after incorporation of a foreignion was also studied for its facile recovery from the reaction medium (Liang et al., 2012). This is important especially for their practical applications in wastewater treatment at industrial scale. The magnetic property of magnetite is affected by the cationic pattern in tetrahedral and octahedral sites (Lelis et al., 2004) as well as the synthesis conditions (Hu et al., 2013). In addition, the descent in particle size could also result in a rise in magnetic order on the surface of the particles (Haneda and Morrish, 1988). As reported (Cornell and Schwertmann, 2003), the magnetic hyperfine field was affected by the isomorphically replacement of iron with other cations. It was observed that $\mathrm{Fe}^{2+}$ replacement with $\mathrm{Co}^{2+}$ on octahedral sites resulted in an increase in the internal hyperfine magnetic field of the site from $46.2 \mathrm{~T}$ of pure magnetite to $47.4 \mathrm{~T}$ in $\mathrm{Fe}_{2.24} \mathrm{Co}_{0.75} \mathrm{O}_{0.01} \mathrm{O}_{4}$ along with increment in Co content but it stayed almost unaltered in tetrahedral sites (Lelis et al., 2004). Silva et al. (2009) reported a decrease in hyperfine field value in the hematite with $\mathrm{Nb} \%$ of 1.49 due to the replacement of magnetic ion with non-magnetic one and disbalance in the electronic charges between $\mathrm{Fe}^{3+}$ and $\mathrm{Nb}^{5+}$ that came about vacancies in the catalyst structure. Moreover, higher concentrations of $\mathrm{Nb}(\% \mathrm{Nb}=5.00$ and 9.24) resulted in smaller sized superparamagnetic hematites. Similarly, substitution of iron in goethite with non-magnetic Nb resulted in the decrease in magnetic order of the catalyst by increase in the $\mathrm{Nb}$ content (Oliveira et al., 2008).

In heterogeneous Fenton system using iron oxides, the stability of the catalyst is a prominent factor from both catalytic and economical viewpoints (Yang et al., 2009b). The stability is often measured by the magnitude of iron leaching in the reaction medium. In stable catalysts, the concentration of dissolved iron in the solution is below $5 \%$ concerning the initial iron content or is not detectable with iron measuring devices (Pariente et al., 2008). In this condition, the involvement of homogeneous Fenton process in the oxidation of organic pollutants is negligible (Costa et al., 2006) and the catalyst can be run for several times with insignificant decrease in its efficacy (Silva et al., 2009; Zhong et al., 2012). In the case of TMSIOs, the incorporated transition metal is required to be stable in the cation leaching test to prevent probable pollution from their entrance to environment. In terms of iron dissolution, the catalyst, Si-goethite had the highest stability at the Si/Fe ratio of 0.2 and the upper values did not enhance the stability (Yuan et al., 2011). In their study, it was reported that the decrease in photocatalytic activity of $\mathrm{Si}-\mathrm{FeOOH}$ was inconsiderable where the amount of dimethyl phthalate removal for six runs was respectively 97.0, 94.6, 92.6, 91.0, 89 and $87.1 \%$ with only $10 \%$ decrease in sixth run as compared to fresh catalyst.
Accordingly, iron leaching promoters are of concern for its effective action. Numerous factors control this rate, such as $\mathrm{pH}$, temperature, irradiation source and intensity, contact time, type and concentration of oxidant and presence of other molecules in the reaction medium like carboxylic acids (Rodríguez et al., 2009a,b). The reaction between iron species and number of carboxylic acids produce ferricarboxylate complexes that initiate oxidation process by adsorbing UV-A radiation with high quantum yield (Franch et al. 2004; Rodríguez et al., 2009b). For example, carboxylate complexes of tartaric, malic, oxalic and citric acids are active in UV-A region but malonic acid complexes adsorb light under $320 \mathrm{~nm}$. Moreover, succinic and maleic acids do not produce ferricarboxylate complexes and consequently, they do not have positive effect on contaminant oxidation (Rodríguez et al., 2009b). Rodríguez et al. (2009a) reported that oxalic acid was the most effective carboxylic acid for iron leaching when compared with malic, citric and tartaric acids. The authors found that this effect was higher for magnetite in contrast to hematite. In addition, the UVA/iron oxide/ oxalic acid $/ \mathrm{H}_{2} \mathrm{O}_{2} / \mathrm{TiO}_{2}$ oxidation system represented higher bisphenol A removal than other studied oxidation systems.

\subsection{Adsorption capacity}

In heterogeneous Fenton reactions, the electrostatic interaction between the surface of the catalyst and the probe molecule is a very important factor and removal of probe molecule from reaction solution is accounted by its adsorption on surface of TMSIO (Yang et al., 2009b). For this purpose, the organic contaminant and the heterogeneous iron catalyst are stirred together for a period of time (2-3 h) to achieve adsorption equilibrium (Hanna et al., 2008). Several factors such as pH (Hanna et al., 2008; Hu et al., 2013), contact time, initial concentration of contaminant (Ai et al., 2011) and physico-chemical properties (Liang et al., 2013) affect the adsorption capacity of the catalyst. In $\mathrm{UV} / \mathrm{Si}-\mathrm{FeOOH} / \mathrm{H}_{2} \mathrm{O}_{2}$ system (Yuan et al., 2011), for example, the surface charge of the catalyst and dimethyl phthalate (DMP) hydrolysis was found to be $\mathrm{pH}$ dependent. Electron-donating groups in DMP induces negative charge to DMP at $\mathrm{pH}$ values higher than zero potential charge of $\mathrm{Si}-$ FeOOH (8.4) and on the other side, at $\mathrm{pH}<8.4$, the surface of the catalyst is positively charged which is desirable for DMP adsorption. In this study, $\mathrm{pH}=5$ improved DMP removal by $10-15 \%$. The reactions involved in DMP degradation under UV irradiation has been summarised as follows:

$$
\begin{aligned}
& \equiv \mathrm{Fe}^{\mathrm{III}} \mathrm{OH}+\mathrm{H}_{2} \mathrm{O}_{2} \rightarrow \equiv \mathrm{Fe}^{\mathrm{III}} \mathrm{OOH}+\mathrm{H}_{2} \mathrm{O} \\
& \equiv \mathrm{Fe}^{\mathrm{III}} \mathrm{OOH}+\mathrm{h} \cup \rightarrow \equiv \mathrm{Fe}^{\mathrm{III}}=\mathrm{O}+\cdot \mathrm{OH} \\
& \equiv \mathrm{Fe}^{\mathrm{III}}=\mathrm{O}+\mathrm{H}_{2} \mathrm{O} \rightarrow \equiv \mathrm{Fe}^{\mathrm{III}} \mathrm{OH}+\cdot \mathrm{OH}
\end{aligned}
$$

$\mathrm{DMP}+\cdot \mathrm{OH} \rightarrow$ intermediate products or $\mathrm{CO}_{2}+\mathrm{H}_{2} \mathrm{O}$

Under the influence of UV irradiation, both, produced holes from $\mathrm{Si}-\mathrm{FeOOH}$ semiconductor and the electron-hole pairs $\left(\mathrm{e}^{-}-\mathrm{h}^{+}\right)$, could react with adsorbed hydrogen peroxide or ${ }^{-} \mathrm{OH}$ anion and yield $\bullet \mathrm{OH}$ radicals. Moreover, other strong oxidising species such as $\cdot \mathrm{O}_{2}^{-}$also were produced from the reduction of adsorbed $\mathrm{O}_{2}$ on the catalyst surface over conduction band electrons (Yuan et al., 2011). In a study, Liang et al. (2012) conducted a set of experiments to develop two metals substituted magnetite with exertion of $\mathrm{Ti}^{4+}$ and $\mathrm{V}^{3+}$ cations to its spinel structure by co-precipitation method. This incorporation improved the adsorption activity of magnetite in which all the $\mathrm{Fe}_{3-x-x^{\prime}} \mathrm{Ti}_{x} \mathrm{~V}_{x^{\prime}} \mathrm{O}_{4}$ samples had higher saturated adsorbed amount than $\mathrm{Fe}_{3} \mathrm{O}_{4}$ with greater dependence on $\mathrm{Ti}^{4+}$ content than $\mathrm{V}^{3+}$. 
Silva et al. (2011) investigated the effect of pre-activating of the catalyst with $\mathrm{H}_{2} \mathrm{O}_{2}$ on its efficiency in Fenton reaction. In this study, $\mathrm{H}_{2} \mathrm{O}_{2}$-treated $\mathrm{Nb}$-doped iron oxide, mainly comprised of hematite, maghemite and $\mathrm{FeNb}_{2} \mathrm{O}_{6}$, was characterised by peroxo groups $(\mathrm{Nb}-$ $\mathrm{O}-\mathrm{O}$ ) on its surface derived from the presence of $\mathrm{Nb}$ (Esteves et al., 2008) that relatively promoted methylene blue discoloration (Silva et al., 2011). For non-treated catalyst, there was an aging time or delay in the degradation due to catalyst hydroxylation step (Ramalho et al., 2009) (Fig. 2).

\subsection{Catalytic activity}

Review of the literature clearly reveals that the introduced active cation not only changes the characteristics of the catalyst with respect to the active sites for enhanced pollutant degradation but is directly involved in oxidation process via the conjugation of redox pairs and their efficient role in generation of active species. For instance, the presence of $\mathrm{Cr}$ in magnetite structure, even at low concentration, $\mathrm{Fe}_{2.93} \mathrm{Cr}_{0.07} \mathrm{O}_{4}$, did not affect the catalyst's surface area and size while it improved the discoloration and oxidation rate considerably mainly because of the participation of $\mathrm{Fe}^{3+} / \mathrm{Fe}^{2+}$ and $\mathrm{Cr}^{2+} / \mathrm{Cr}^{3+}$ pairs in $\mathrm{H}_{2} \mathrm{O}_{2}$ oxidation cycle (Fig. 1) (Magalhães et al., 2007).

While considering the activity of the produced TMSIO catalyst, it has been generally evaluated either by measuring the amount of generated oxygen through hydrogen peroxide decomposition (Magalhães et al., 2007; Oliveira et al., 2007; Zhong et al., 2013) (Eq. (14)), and/or participation in Fenton-like reactions for discoloration or organic pollutant oxidation (Table 3 ).

$2 \mathrm{H}_{2} \mathrm{O}_{2} \rightarrow 2 \mathrm{H}_{2} \mathrm{O}+\mathrm{O}_{2} \uparrow$

All the introduced transition metals do not intensify the activity of the catalyst. The incorporated $\mathrm{Ni}^{2+}$ species generally replaced $\mathrm{Fe}^{2+}$ cations in magnetite structure that are accountable for Fenton initiating step. On the other hand, $\mathrm{Ni}^{2+}$ ions are stable and cannot start the radical reaction (Eq. (1)); for that reason, its occupancy in magnetite structure had an inhibitory effect on $\mathrm{H}_{2} \mathrm{O}_{2}$ decomposition and methylene blue degradation reactions (Costa et al., 2006).

\subsection{1. $\mathrm{H}_{2} \mathrm{O}_{2}$ decomposition}

In Fenton oxidation system, decontamination process commonly starts by generation of hydroxyl radicals through hydrogen peroxide decomposition on the surface of the TMSIOs catalyst as is for iron oxides (Eq. (15)):

$$
\equiv \mathrm{M}_{\text {surf }}^{n+}+\mathrm{H}_{2} \mathrm{O}_{2} \rightarrow \equiv \mathrm{M}_{\text {surf }}^{(n+1)+}+{ }^{\cdot} \mathrm{OH}+\mathrm{OH}^{-}
$$

On the other side, the occurrence of mechanisms other than radical generation comes into play when the presence of radical scavengers such as phenol, hydroquinone or ascorbic acid does not affect the rate of $\mathrm{H}_{2} \mathrm{O}_{2}$ decomposition (Oliveira et al., 2008). This may result from the rivalry between organic compound and active sites (Costa et al., 2003). If so, Oliveira et al. (2008) and Costa et al.

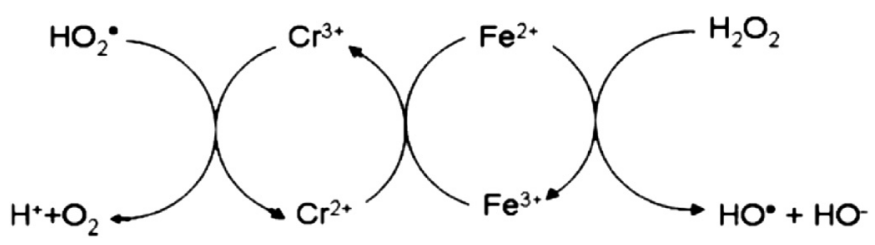

Fig. 1. Proposed mechanism for the participation of $\mathrm{Cr}$ in Fenton reaction (Magalhães et al., 2007).

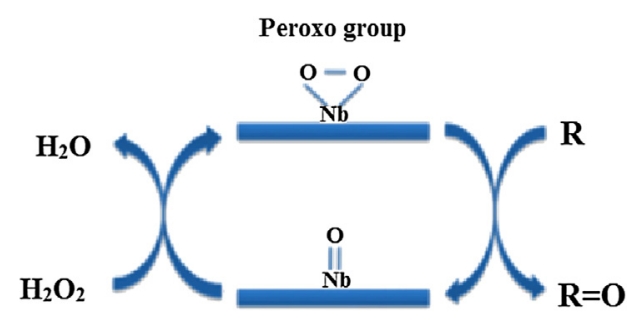

Peroxo group regeneration

oxidized organic comound

Fig. 2. Oxidation of organic compound by peroxo group on the surface of Nb-iron oxide catalyst treated by $\mathrm{H}_{2} \mathrm{O}_{2}$ (Silva et al., 2011).

(2003) proposed the role of oxygen vacancies in production of $\mathrm{O}_{2}$ from $\mathrm{H}_{2} \mathrm{O}_{2}$ as Equations (16) and (17):

$\mathrm{M}_{\text {surf }}+\mathrm{H}_{2} \mathrm{O}_{2} \rightarrow \mathrm{M}-\mathrm{O}_{\text {surf }}+\mathrm{H}_{2} \mathrm{O}$

$\mathrm{M}-\mathrm{O}_{\text {surf }}+\mathrm{H}_{2} \mathrm{O}_{2} \rightarrow \mathrm{M}_{\text {surf }}+\mathrm{H}_{2} \mathrm{O}+\mathrm{O}_{2}$

Higher $\mathrm{H}_{2} \mathrm{O}_{2}$ decomposition rates over TMSIOs demonstrates higher activity of the catalyst and consequently, higher Fenton oxidation efficiency for organic contaminant removal (Xue et al., 2009a). Guimaraes et al. (2009) reported that $\mathrm{H}_{2} \mathrm{O}_{2}$ decomposition rate was significantly high over the surface of cu-doped goethite catalyst, containing both copper and iron active cations, in contrast with pure goethite holding solely $\mathrm{Fe}^{\mathrm{III}}$ species. The results indicated that $\mathrm{Cu}^{2+}$ inclusion into the structure of goethite accelerated $\mathrm{H}_{2} \mathrm{O}_{2}$ decomposition on the surface of the catalyst and resulted in generation of hydroxylation compounds as main byproducts. Costa et al. (2003) compared the catalytic activity of pure magnetite $\left(\mathrm{Fe}_{3} \mathrm{O}_{4}\right)$ and cobalt oxide. Although $\mathrm{Co}_{3} \mathrm{O}_{4}$ represented higher activity to some degree, but it was distinctly less in relation to cobalt substituted magnetite catalyst. Furthermore, Silva et al. (2009) observed that a significant methylene blue removal by $\mathrm{Nb}$-containing hematite was started with 25 min delay, the time which the catalyst surface was activated by $\mathrm{Fe}^{3+}$ reduction for higher $\mathrm{H}_{2} \mathrm{O}_{2}$ decomposition. The authors reported that the presence of other organic compounds in the reaction medium prevented $\mathrm{H}_{2} \mathrm{O}_{2}$ decomposition forcibly due to the competition between organic compounds and $\mathrm{H}_{2} \mathrm{O}_{2}$ for active sites and they proposed radical mechanism for oxidation reactions.

\subsubsection{Organic contaminant degradation}

Amongst various organic compounds that are used for activity evaluation of TMSIOs, the dye methylene blue (MB) has been studied frequently due to its presence in most textile industrial wastewaters, dissolution in water and easy spectrophotometric measurement (Silva et al., 2011). Data on the degradation of recalcitrant organic compounds using TMSIOs in Fenton reactions are summarised in Table 3. The studies for MB degradation/ discoloration at concentrations of $50-100 \mathrm{mg} \mathrm{L}^{-1}$ and at its natural $\mathrm{pH}$ (6.0) show that its discoloration rate has been generally higher with TMSIOs than of pure iron oxide (Costa et al., 2006; Liang et al., 2010; Oliveira et al., 2008; Silva et al., 2009) and the catalytic efficiency was increased simultaneously by increasing the imported transition metal content (Liang et al., 2010, 2012; Oliveira et al., 2008; Silva et al., 2009). Although, Magalhães et al. (2007) reported a higher MB degradation at lower $\mathrm{Cr}$ content in $\mathrm{Fe}_{3 x} \mathrm{Cr}_{x} \mathrm{O}_{4}$ $(x=0.00,0.07,0.26,0.42$ and 0.51$)$, higher $\mathrm{Cr}$ content was desirable for hydrogen peroxide decomposition to oxygen. However, being thermodynamically unfavourable for $\mathrm{Fe}^{3+}$ reduction to $\mathrm{Fe}^{2+}$ in Fenton reaction, $\mathrm{Fe}_{2.46} \mathrm{Ni}_{0.54} \mathrm{O}_{4}$ could remove only $10 \mathrm{mg} \mathrm{L}^{-1}$ of $\mathrm{MB}$ with initial concentration of $100 \mathrm{mg} \mathrm{L}^{-1}$ within $50 \mathrm{~min}$. Besides, 
Table 3

Oxidation of various organic pollutants catalysed by transition metal substituted iron oxide through Fenton reactions.

\begin{tabular}{|c|c|c|c|c|c|c|c|}
\hline \multirow[t]{2}{*}{ Compound } & \multirow[t]{2}{*}{ Catalyst } & \multicolumn{4}{|c|}{ Operational condition } & \multirow[t]{2}{*}{ Optimal performance } & \multirow[t]{2}{*}{ References } \\
\hline & & {$\left[\mathrm{H}_{2} \mathrm{O}_{2}\right]$} & $\mathrm{pH}$ & $\mathrm{T}\left({ }^{\circ} \mathrm{C}\right)$ & $\lambda$ (su et al.) & & \\
\hline $\begin{array}{l}\text { Methylene blue [MB] } \\
\quad 50 \mathrm{mg} \mathrm{L}^{-1}\end{array}$ & $\begin{array}{l}\text { Cr-magnetite } \\
\mathrm{Fe}_{3-x} \mathrm{Cr}_{x} \mathrm{O}_{4}(15 \mathrm{mg})\end{array}$ & $0.3 \mathrm{mg} \mathrm{L}^{-1}$ & 6.0 & $25 \pm 1$ & - & $\begin{array}{l}\text { Higher degradation rate at } \\
\text { lower } \mathrm{Cr} \text { content, decrease in } \\
\text { discoloration rate and } \mathrm{TOC} \\
\text { removal by increase in } \mathrm{Cr} \\
\text { content mainly due to the } \\
\text { decrease in } \mathrm{Fe}^{2+} \text {. }\end{array}$ & $\begin{array}{l}\text { (Magalhães } \\
\text { et al., 2007) }\end{array}$ \\
\hline $\begin{array}{l}\text { Tetrabromobis-phenol A } \\
\text { [TBBPA] } 20 \mathrm{mg} \mathrm{L}^{-1}\end{array}$ & $\begin{array}{l}\text { Titanomagnetite } \\
\mathrm{Fe}_{2.02} \mathrm{Ti}_{0.98} \mathrm{O}_{4} 0.125 \mathrm{~g} \mathrm{~L}^{-1}\end{array}$ & $10 \mathrm{mmol} \mathrm{L}^{-1}$ & 6.5 & 25 & - & $\begin{array}{l}>97 \% \text { TBBPA degradation in UV/ } \\
\mathrm{Fe}_{2.02} \mathrm{Ti}_{0.98} \mathrm{O}_{4} / \mathrm{H}_{2} \mathrm{O}_{2} \text { system, } \\
\approx 75 \% \text { in } \mathrm{UV} / \mathrm{H}_{2} \mathrm{O}_{2 \text { tr system }} \\
\text { within } 240 \text { min of UV } \\
\text { irradiation. }\end{array}$ & $\begin{array}{l}\text { (Zhong et al., } \\
\text { 2012) }\end{array}$ \\
\hline $\begin{array}{l}\text { Methylene blue } \\
{[\mathrm{MB}] 100 \mathrm{mg} \mathrm{L}^{-1}}\end{array}$ & $\begin{array}{l}\mathrm{Fe}_{2.46} \mathrm{Ni}_{0.54} \mathrm{O}_{4} \\
\mathrm{Fe}_{2.47} \mathrm{Mn}_{0.53} \mathrm{O}_{4} \\
\mathrm{Fe}_{2.25} \mathrm{Co}_{0.75} \mathrm{O}_{4}(30 \mathrm{mg})\end{array}$ & $2.5 \mathrm{~mol} \mathrm{~L}^{-1}$ & - & $25 \pm 1$ & 633 & $\begin{array}{l}10 \% \text { colour removal within } \\
50 \text { min using } \mathrm{Fe}_{2.46} \mathrm{Ni}_{0.54} \mathrm{O}_{4} \text {, } \\
\text { complete discoloration of the } \\
\text { solution in } 5 \text { and } 10 \text { min using } \\
\mathrm{Fe}_{2.47} \mathrm{Mn}_{0.53} \mathrm{O}_{4} \text { and } \\
\mathrm{Fe}_{2.25} \mathrm{Co}_{0.75} \mathrm{O}_{4} \text { respectively. }\end{array}$ & $\begin{array}{l}\text { (Costa et al., } \\
\text { 2003) }\end{array}$ \\
\hline $\begin{array}{l}\text { Chlorobenzene [CBZ] } \\
\qquad 30 \mathrm{mg} \mathrm{L}^{-1}\end{array}$ & $\begin{array}{l}\text { Mn-magnetite } \\
\mathrm{Fe}_{3-x} \mathrm{Mn}_{x} \mathrm{O}_{4}(30 \mathrm{mg})\end{array}$ & $2.5 \mathrm{~mol} \mathrm{~L}^{-1}$ & - & $25 \pm 1$ & - & $\begin{array}{l}14,7,5 \text { and }<1 \% \text { Chlorobenzene } \\
\text { degradation for the reactions } \\
\text { using } \mathrm{Fe}_{2.47} \mathrm{Mn}_{0.53} \mathrm{O}_{4} \text {, } \\
\mathrm{Fe}_{2.74} \mathrm{Mn}_{0.26} \mathrm{O}_{4}, \mathrm{Fe}_{2.79} \mathrm{Mn}_{0.21} \mathrm{O}_{4} \\
\text { and } \mathrm{Fe}_{3} \mathrm{O}_{4} \text {, respectively. }\end{array}$ & $\begin{array}{l}\text { (Costa et al., } \\
\text { 2003; Oliveira } \\
\text { et al., 2000) }\end{array}$ \\
\hline $\begin{array}{l}\text { Methylene blue [MB] } \\
\quad 0.1 \mathrm{~g} \mathrm{~L}^{-1}\end{array}$ & $\begin{array}{l}\gamma-\mathrm{Fe}_{2} \mathrm{O}_{3} \\
\alpha-\mathrm{Fe}_{2} \mathrm{O}_{3} \\
\mathrm{Fe}_{3-x} \mathrm{M}_{x} \mathrm{O}_{4}(\mathrm{M}=\mathrm{Co} \& \mathrm{Mn}) \\
(30 \mathrm{mg})\end{array}$ & $\begin{array}{l}0.3 \mathrm{~mol} \mathrm{~L}^{-1} \\
(10 \mathrm{~mL})\end{array}$ & $5-6.5$ & 25 & - & $\begin{array}{l}\text { Not remarkable discoloration } \\
\text { with } \mathrm{Fe}_{2} \mathrm{O}_{3} \text { oxides, complete } \\
\text { colour removal and higher } \\
\text { oxidation by } \mathrm{Fe}_{3-x} \mathrm{M}_{x} \mathrm{O}_{4} \text { within } \\
5-10 \text { min. }\end{array}$ & $\begin{array}{l}\text { (Costa et al., } \\
\text { 2006) }\end{array}$ \\
\hline $\begin{array}{l}\text { Chlorobenzene [CBZ] } \\
\quad 0.02 \mathrm{~g} \mathrm{~L}^{-1}\end{array}$ & $\begin{array}{l}\text { Mn-magnetite } \\
\mathrm{Fe}_{3-x} \mathrm{Mn}_{x} \mathrm{O}_{4}(30 \mathrm{mg})\end{array}$ & $\begin{array}{l}0.3 \mathrm{~mol} \mathrm{~L}^{-1} \\
\text { or } 10.2 \mathrm{~g} \mathrm{~L}^{-1}\end{array}$ & - & $25 \pm 1$ & - & $\begin{array}{l}1,5,7 \text { and } 14 \% \mathrm{CBZ} \text { removal } \\
\text { using } \mathrm{Fe}_{3} \mathrm{O}_{4}, \mathrm{Fe}_{2.79} \mathrm{Mn}_{0.21} \mathrm{O}_{4} \text {, } \\
\mathrm{Fe}_{2.74} \mathrm{Mn}_{0.26} \mathrm{O}_{4} \text { and } \\
\mathrm{Fe}_{2.47} \mathrm{Mn}_{0.53} \mathrm{O}_{4} \text { respectively } \\
\text { within } 30 \text { min, }\end{array}$ & $\begin{array}{l}\text { (Costa et al., } \\
2006)\end{array}$ \\
\hline $\begin{array}{l}\text { Methylene blue UV [MB] } \\
\quad 0.2 \mathrm{mmol} \mathrm{L}^{-1}(500 \mathrm{~mL})\end{array}$ & $\begin{array}{l}\text { Ti-V-magnetite } \\
\mathrm{Fe}_{3-x-x^{\prime}} \mathrm{Ti}_{x} \mathrm{~V}_{x^{\prime}} \mathrm{O}_{4}\left(1.0 \mathrm{~g} \mathrm{~L}^{-1}\right)\end{array}$ & $10 \mathrm{mmol} \mathrm{L}^{-1}$ & 7.0 & 25 & 365 & $\begin{array}{l}\text { Increase in MB discoloration } \\
\text { from } 48 \% \text { to } 96 \% \text { by increase in } \\
\text { Ti content from } x=0.0 \text { to } \\
x=0.69 \text { after } 120 \mathrm{~min}\end{array}$ & $\begin{array}{l}\text { (Liang et al., } \\
\text { 2012) }\end{array}$ \\
\hline $\begin{array}{l}\text { Methylene blue [MB] } \\
\qquad 100 \mathrm{mg} \mathrm{L}^{-1}(400 \mathrm{~mL})\end{array}$ & $\begin{array}{l}\text { Titanomagnetite } \\
\mathrm{Fe}_{3-x} \mathrm{Ti}_{x} \mathrm{O}_{4} \\
\left(1.0 \mathrm{~g} \mathrm{~L}^{-1}\right)\end{array}$ & $0.30 \mathrm{~mol} \mathrm{~L}^{-1}$ & 6.8 & 30 & - & $\begin{array}{l}\text { Higher activity for Ti-magnetite } \\
\text { than pure magnetite, Decrease } \\
\text { in residual MB with the increase } \\
\text { in Ti content. }\end{array}$ & $\begin{array}{l}\text { (Yang et al., } \\
\text { 2009a) }\end{array}$ \\
\hline $\begin{array}{l}\text { Methylene blue [MB] } \\
\quad 0.2 \mathrm{mmol} \mathrm{L}^{-1}(200 \mathrm{~mL})\end{array}$ & $\begin{array}{l}\text { V-magnetite } \\
\mathrm{Fe}_{3-\mathrm{x}} \mathrm{V}_{\mathrm{x}} \mathrm{O}_{4} \\
0 \leq x \leq 0.34\left(1.0 \mathrm{~g} \mathrm{~L}^{-1}\right)\end{array}$ & $100 \mathrm{mmol} \mathrm{L}^{-1}$ & 10.0 & 25 & - & $\begin{array}{l}\text { Colour removal of } 41,60,81 \\
\text { and } 93 \% \text { of } \mathrm{MB} \text { within } 11 \mathrm{~h} \\
\text { using } \mathrm{Fe}_{3} \mathrm{O}_{4}, \mathrm{Fe}_{2.84} \mathrm{~V}_{0.16} \mathrm{O}_{4} \\
\mathrm{Fe}_{2.74} \mathrm{~V}_{0.26} \mathrm{O}_{4} \text { and } \mathrm{Fe}_{2.66} \mathrm{~V}_{0.34} \mathrm{O}_{4} \\
\text { respectively. }\end{array}$ & $\begin{array}{l}\text { (Liang et al., } \\
\text { 2010) }\end{array}$ \\
\hline $\begin{array}{l}\text { Methylene blue [MB] } \\
\qquad 50 \mathrm{mg} \mathrm{L}^{-1}(10 \mathrm{~mL})\end{array}$ & $\begin{array}{l}\text { Nb-Hematite } \\
\mathrm{Fe}_{2-x} \mathrm{Nb}_{x} \mathrm{O}_{3}\left(10 \mathrm{~g} \mathrm{~L}^{-1}\right)\end{array}$ & $0.3 \mathrm{~mol} \mathrm{~L}^{-1}$ & 6.0 & $25 \pm 1$ & - & $\begin{array}{l}\text { Low discoloration with pure } \\
\text { hematite and } \mathrm{Hm}-\mathrm{Nb} 2,70 \% \\
\text { colour removal and } 25 \% \text { TOC } \\
\text { removal after } 60 \text { min with Hm- } \\
\text { Nb10. }\end{array}$ & $\begin{array}{l}\text { (Silva et al., } \\
\text { 2009) }\end{array}$ \\
\hline $\begin{array}{l}\text { Methylene blue [MB] } \\
\qquad 50 \mathrm{mg} \mathrm{L}^{-1}(10 \mathrm{~mL})\end{array}$ & $\begin{array}{l}\text { Nb-hematite-maghemite } \\
\text { treated by } \mathrm{H}_{2} \mathrm{O}_{2}\left(1 \mathrm{~g} \mathrm{~L}^{-1}\right)\end{array}$ & $\begin{array}{l}8.0 \mathrm{mM} \\
30 \% \mathrm{v} / \mathrm{v}\end{array}$ & 6.0 & $25 \pm 1$ & - & $\begin{array}{l}73 \% \mathrm{MB} \text { removal using treated } \\
\text { catalyst compared to } 30 \% \mathrm{MB} \\
\text { removal by non-treated } \\
\text { samples within } 60 \mathrm{~min} .\end{array}$ & $\begin{array}{l}\text { (Silva et al., } \\
\text { 2011) }\end{array}$ \\
\hline $\begin{array}{l}\text { Bromophenol Blue, } \\
\text { Chicago Sky Blue, Evans } \\
\text { Blue and Naphthol Blue } \\
\text { Black [dye] } 50 \mathrm{mg} \mathrm{L}^{-1}\end{array}$ & $\mathrm{FeO}-\mathrm{Fe}_{2} \mathrm{O}_{3}\left(25 \mathrm{mg} \mathrm{mL}^{-1}\right)$ & $100 \mathrm{mmol} \mathrm{L}^{-1}$ & 6.6 & 30 & - & $\begin{array}{l}90 \% \text { colour removal within } 24 \mathrm{~h} \text {, } \\
\text { the fast decomposition rate at } \\
\text { first hour. }\end{array}$ & $\begin{array}{l}\text { (Baldrian et al., } \\
\text { 2006) }\end{array}$ \\
\hline $\begin{array}{l}\text { Naphthol Blue Black [NBB] } \\
500 \mathrm{mg} \mathrm{L}^{-1}, \mathrm{COD}_{0} 1.80\end{array}$ & $\begin{array}{l}\mathrm{MO}-\mathrm{Fe}_{2} \mathrm{O}_{3},(\mathrm{M}: \mathrm{Mn}, \mathrm{Co}, \\
\mathrm{Cu}, \mathrm{Fe}) \\
25 \mathrm{mg} \mathrm{mL}^{-1}\end{array}$ & $100 \mathrm{mmol} \mathrm{L}^{-1}$ & $6.0-6.6$ & 30 & - & $\begin{array}{l}\text { COD removal of } 97 \%, 92 \%, 88 \% \text { \& } \\
75 \% \text { and colour removal of } 85 \% \text {, } \\
67 \%, 53 \% \text { \& } 58 \% \text { using the } \\
\text { catalysts of } \mathrm{Cu}, \mathrm{Co}, \mathrm{Fe} \& \mathrm{Mn} \\
\text { respectively. }\end{array}$ & $\begin{array}{l}\text { (Baldrian et al., } \\
\text { 2006) }\end{array}$ \\
\hline $\begin{array}{l}\text { Dimethyl phthalate [DMP] } \\
7.7 \mathrm{mg} \mathrm{L}^{-1}(100 \mathrm{~mL})\end{array}$ & $\begin{array}{l}\mathrm{Si}-\mathrm{FeOOH} \\
0.5 \mathrm{~g} \mathrm{~L}^{-1}\end{array}$ & $2 \mathrm{mmol} \mathrm{L}^{-1}$ & 5.0 & 25 & 365 & $\begin{array}{l}97 \% \text { DMP degradation within } \\
30 \mathrm{~min} \text {. }\end{array}$ & $\begin{array}{l}\text { (Yuan et al., } \\
\text { 2011) }\end{array}$ \\
\hline $\begin{array}{l}\text { Methylene blue [MB] } \\
\quad 50 \mathrm{mg} \mathrm{L}^{-1}(10 \mathrm{~mL})\end{array}$ & $\begin{array}{l}\mathrm{Nb}-\mathrm{FeOOH} \\
(11 \% \mathrm{Nb}) 1 \mathrm{~g} \mathrm{~L}^{-1}\end{array}$ & $0.3 \mathrm{~mol} \mathrm{~L}^{-1}$ & 6.0 & $25 \pm 1$ & - & $\begin{array}{l}15 \% \text { discoloration after } 120 \mathrm{~min} \\
\text { by pure goethite, } \approx 85 \% \text { colour } \\
\text { removal using } \mathrm{Nb} 11-\mathrm{FeOOH} \\
\text { within } 120 \mathrm{~min} \text {. }\end{array}$ & $\begin{array}{l}\text { (Oliveira et al., } \\
\text { 2008) }\end{array}$ \\
\hline $\begin{array}{l}\text { Quinoline } \\
{[\mathrm{Q}] 10 \mathrm{mg} \mathrm{L}^{-1}(9.9 \mathrm{~mL})}\end{array}$ & $\begin{array}{l}\mathrm{Ni}-\mathrm{FeOOH} \\
1 \mathrm{~g} \mathrm{~L}^{-1}\end{array}$ & $\begin{array}{l}1.1 \mathrm{~mL} \\
5 \% \mathrm{v} / \mathrm{v}\end{array}$ & 6.0 & $25 \pm 1$ & - & $\begin{array}{l}28 \% \mathrm{Q} \text { removal after } 5 \mathrm{~h} \text { by pure } \\
\text { goethite, } 70 \% \mathrm{Q} \text { removal within } \\
5 \mathrm{~h} .\end{array}$ & $\begin{array}{l}\text { (de Souza et al., } \\
\text { 2010) }\end{array}$ \\
\hline
\end{tabular}


complete discoloration of the solution was achieved using $\mathrm{Fe}_{2.47} \mathrm{Mn}_{0.53} \mathrm{O}_{4}$ and $\mathrm{Fe}_{2.25} \mathrm{Co}_{0.75} \mathrm{O}_{4}$ within 5 and 10 min due to their desirable effect on the rate of $\mathrm{Fe}^{2+}$ regeneration (Costa et al., 2003). On the other side, the higher activity of $\mathrm{Fe}_{2} \mathrm{NiO}_{4}$ catalyst towards Hydroxyl radical generation (Equation (18)) (Litter, 1999) in photo Fenton-like reaction and its effective degradation of tetrabromobisphenol A (TBBPA), was ascribed based on the lower oxidation potential of $\mathrm{Ni}^{2+} / \mathrm{Ni}^{3+}$ redox pair on the catalyst surface compared to $\mathrm{H}_{2} \mathrm{O}_{2}$ ( $-1.74 \mathrm{~V}$ vs. $1.776 \mathrm{~V}$ ) (Zhong et al., 2013).

$\equiv \mathrm{M}_{\text {surf }}^{n+}+\mathrm{H}_{2} \mathrm{O}_{2} \rightarrow \equiv \mathrm{M}_{\text {surf }}^{(n+1)+}+2 \cdot \mathrm{OH}$

In the study conducted by Zhong et al. (2013), although the oxidation potential of $\mathrm{Co}^{2+} / \mathrm{Co}^{3+}$ was higher than of $\mathrm{H}_{2} \mathrm{O}_{2}(1.81 \mathrm{~V}$ vs. $1.776 \mathrm{~V}$ ), it enhanced the catalytic activity of the respective TMSIO that could be due to the domination of other mechanism. The likely mechanism is the role of these ions in prohibition of the recombination of photo-generated electorns $\left(e^{-}\right)$and holes $\left(h^{+}\right)$on catalyst surface (Büchler et al., 1998) and extending the existence time of charge carriers. Accordingly, the catalytic activity of magnetite was improved in the order of $\mathrm{Cr}>\mathrm{Ni} \approx \mathrm{Ti}>\mathrm{Mn}>\mathrm{Co}$.

Indeed, higher activity could be driven at an optimum ratio of incorporated active cation to iron species and the concentration above this value may not affect the activity remarkably. For example, Yuan et al. (2011) observed that the amount of degraded dimethyl phthalate (DMP) by $\mathrm{Si}-\mathrm{FeOOH}$ was the highest at $\mathrm{Si} / \mathrm{Fe}$ ratio of 0.2 and both higher and lower values than 0.2 decreased degradation percentages. This is attributed to the decrease in UV transmission into the solution caused by the formation of suspended indigent catalyst particles at lower ratios; and at higher values, the active sites were covered with high concentrations of $\mathrm{SiO}_{2}$ and resulted in lower ${ }^{\circ} \mathrm{OH}$ radical generation from $\mathrm{H}_{2} \mathrm{O}_{2}$. Nevertheless, the increase in the amount of incorporated $\mathrm{Mn}$ and Co resulted in a considerable increase in the activity of the produced catalyst where $\mathrm{Fe}_{3} \mathrm{O}_{4}$ (pure magnetite) showed lower activity compared to the $\mathrm{Fe}_{3-\mathrm{x}} \mathrm{Mn}_{\mathrm{x}} \mathrm{O}_{4}$ and $\mathrm{Fe}_{3-\mathrm{x}} \mathrm{Co}_{\mathrm{x}} \mathrm{O}_{4}$ catalysts and amongst them, $\mathrm{Fe}_{2.47} \mathrm{Mn}_{0.53} \mathrm{O}_{4}$ and $\mathrm{Fe}_{2.25} \mathrm{Co}_{0.75} \mathrm{O}_{4}$ represented the highest activity for the above mentioned reactions (Costa et al., 2003).

A mixture of natural niobia $\left(\mathrm{Nb}_{2} \mathrm{O}_{5}\right)$ and iron oxides resulted in formation of a composite catalyst containing goethite $(\alpha \mathrm{FeOOH})$ and maghemite $\left(\gamma \mathrm{Fe}_{2} \mathrm{O}_{3}\right)$ as main constitutive iron oxides in its structure (Oliveira et al., 2007). The amount of Niobia in the composite affected the discoloration rate significantly when niobia/iron oxides of $1: 5$ could remove only $50 \%$ of the colour of methylene blue solution while it increased up to $90 \%$ in ratio of $1: 1$.

Yang et al. (2009b) measured element $C$ in the reaction solution to determine the total amount of the adsorbed probe molecule to the surface of titanomagnetite catalyst. The amount of element $\mathrm{C}$ was utmost at time zero of the reaction. After degradation of adsorbed $\mathrm{MB}$ on the Ti-magnetite by $\mathrm{H}_{2} \mathrm{O}_{2}$, the degradation products were desorbed from the catalyst. That was due to their lower electrostatic interaction at neutral $\mathrm{pH}$ values and consequently, the concentration of element $\mathrm{C}$ in the solution was decreased. The results exhibited that the MB degradation with titanomagnetite was $\mathrm{pH}$-dependent and was low at neutral $\mathrm{pH}$ values. In this study, both adsorption and degradation could result in contaminant removal.

\section{Conclusion}

Iron oxides as heterogeneous catalysts demonstrated considerable improvements in Fenton reactions for contaminant removal from polluted medium/sites due to their higher activity under a broad range of $\mathrm{pH}$ in contrast with soluble iron salts. The conclusions derived from the various literature sources can be stated as follows:

1. Transition metal substituted iron oxides provide a new promising class of heterogeneous catalysts that effectively degrade recalcitrant organic compounds in Fenton oxidation system because of their relatively low cost, easy magnetic separation, higher stability and improved adsorption capacity. Some examples are chromium, cobalt and titanium incorporated in magnetite.

2. Amongst various preparation methods, co-precipitation method has been used as a common technique for the production of such catalysts.

3. Almost all of the introduced metals from period four to magnetite structure represented higher activity compared to pure magnetite. The exemption was $\mathrm{Ni}$ that had an inhibitory effect on degradation reaction due to its stability.

4. Two mechanisms were suggested for enhanced activity of TMSIOs: (i) the participation of the thermodynamically favourable redox pairs, $\mathrm{Fe}^{3+} / \mathrm{Fe}^{2+}$ and $\mathrm{M}^{n+} / \mathrm{M}^{n+1}$, in $\mathrm{H}_{2} \mathrm{O}_{2}$ oxidation cycle, to produce $\cdot \mathrm{OH}$ radicals and (ii) generation of oxygen vacancies on the surface of catalyst, resulted from adjustments of unequal charge replacements.

5. This replacement brings about significant improvements in physico-chemical properties of the catalyst such as the decrease in particle size and pore diameter and increase in surface area.

These catalysts are new class in environmental purification aspects and expected to be employed for effective treatment of several industrial wastewaters containing dyes and phenolic compounds such as dyeing and final wastewaters of textile industry and at pre or post treatment steps for petrochemicals and refineries wastewaters. Future studies in this field should address the development of new transition metal substituted iron oxides to obtain significant leap in activity. The magnetic property of the iron oxides should also be maintained for easier separation from reaction medium. In addition, systematic research is required to examine their stability for wider range of operational conditions to avoid the leaching of these metals into reaction solution and their impact on the environment.

\section{Acknowledgements}

The authors are grateful to the University of Malaya High Impact Research Grant (HIR-MOHE-D000037-16001) from the Ministry of Higher Education Malaysia which financially supported this work.

\section{References}

Ai, L., Zhang, C., Liao, F., Wang, Y., Li, M., Meng, L., Jiang, J., 2011. Removal of methylene blue from aqueous solution with magnetite loaded multi-wall carbon nanotube: kinetic, isotherm and mechanism analysis. J. Hazard. Mater. 198, 282-290.

Alexander, M., 1975. Environmental and microbiological problems arising from recalcitrant molecules. Microb. Ecol. 2, 17-27.

Alvarez, M., Rueda, E.H., Sileo, E.E., 2006. Structural characterization and chemical reactivity of synthetic Mn-goethites and hematites. Chem. Geol. 231, 288-299.

Aredes, S., Klein, B., Pawlik, M., 2012. The removal of arsenic from water using natural iron oxide minerals. J. Clean. Prod. 29-30, 208-213.

Babuponnusami, A., Muthukumar, K., 2011. Degradation of phenol in aqueous solution by Fenton, Sono-Fenton and Sono-photo-Fenton methods. Clean Soil, Air, Water 39, 142-147.

Baldrian, P., Merhautová, V., Gabriel, J., Nerud, F., Stopka, P., Hruby, M., Beneš, M.J., 2006. Decolorization of synthetic dyes by hydrogen peroxide with heterogeneous catalysis by mixed iron oxides. Appl. Catal. B: Environ. 66, 258-264.

Benkelberg, H.-J., Warneck, P., 1995. Photodecomposition of iron(III) hydroxo and sulfato complexes in aqueous solution: wavelength dependence of $\mathrm{OH}$ and $\mathrm{SO}_{4}^{-}$ quantum yields. J. Phys. Chem. 99, 5214-5221. 
Berry, F.J., Helgason, Ö., Bohórquez, A., Marco, J.F., McManus, J., Moore, E.A., Mørup, S., Wynn, P.G., 2000. Preparation and characterisation of tin-doped $\alpha_{-}$ FeOOH (goethite). J. Mater. Chem. 10, 1643-1648.

Bredhult, C., Bäcklin, B., Olovsson, M., 2007. Effects of some endocrine disruptors on the proliferation and viability of human endometrial endothelial cells in vitro. Reprod. Toxicol. 23, 550-559.

Büchler, M., Schmuki, P., Böhni, H., Stenberg, T., Mäntylä, T., 1998. Comparison of the semiconductive properties of pputter-deposited iron oxides with the passive film on iron. J. Electrochem. Soc. 145, 378-385.

Chatzisymeon, E., Foteinis, S., Mantzavinos, D., Tsoutsos, T., 2013. Life cycle assessment of advanced oxidation processes for olive mill wastewater treatment. J. Clean. Prod. 54, 229-234.

Chen, Q., Wu, P., Dang, Z., Zhu, N., Li, P., Wu, J., Wang, X., 2010. Iron pillared vermiculite as a heterogeneous photo-Fenton catalyst for photocatalytic degradation of azo dye reactive brilliant orange X-GN. Sep. Purifi. Technol. 71, 315-323.

Chong, M.N., Sharma, A.K., Burn, S., Saint, C.P., 2012. Feasibility study on the application of advanced oxidation technologies for decentralised wastewater treatment. J. Clean. Prod. 35, 230-238.

Chun, J., Lee, H., Lee, S.-H., Hong, S.-W., Lee, J., Lee, C., Lee, J., 2012. Magnetite/ mesocellular carbon foam as a magnetically recoverable fenton catalyst for removal of phenol and arsenic. Chemosphere 89, 1230-1237.

Coker, V.S., Pearce, C.I., Pattrick, R.A.D., van der Laan, G., Telling, N.D., Charnock, J.M., Arenholz, E., Lloyd, J.R., 2008. Probing the site occupancies of Co-, Ni-, and Mnsubstituted biogenic magnetite using XAS and XMCD. Am. Mineral. 93, 11191132.

Cornell, R.M., Schwertmann, U., 2003. The Iron Oxides: Structure, Properties, Reactions, Occurrences, and Uses. Wiley-VCH, Weinheim.

Costa, R.C.C., Lelis, M.d.F.F., Oliveira, L.C.A., Fabris, J.D., Ardisson, J.D., Rios, R.R.V.A., Silva, C.N., Lago, R.M., 2003. Remarkable effect of Co and Mn on the activity of $\mathrm{Fe}_{3-\mathrm{x}} \mathrm{M}_{\mathrm{X}} \mathrm{O}_{4}$ promoted oxidation of organic contaminants in aqueous medium with $\mathrm{H}_{2} \mathrm{O}_{2}$. Catal. Commun. 4, 525-529.

Costa, R.C.C., Lelis, M.F.F., Oliveira, L.C.A., Fabris, J.D., Ardisson, J.D., Rios, R.R.V.A., Silva, C.N., Lago, R.M., 2006. Novel active heterogeneous Fenton system based on $\mathrm{Fe}_{3-\mathrm{x}} \mathrm{M}_{\mathrm{x}} \mathrm{O}_{4}$ ( $\mathrm{Fe}, \mathrm{Co}, \mathrm{Mn}, \mathrm{Ni}$ ): the role of $\mathrm{M}^{2+}$ species on the reactivity towards $\mathrm{H}_{2} \mathrm{O}_{2}$ reactions. J. Hazard. Mater. 129, 171-178.

de Souza, W.F., Guimarães, I.R., Oliveira, L.C.A., Giroto, A.S., Guerreiro, M.C., Silva, C.L.T., 2010. Effect of Ni incorporation into goethite in the catalytic activity for the oxidation of nitrogen compounds in petroleum. Appl. Catal. A: Gen. 381, $36-41$.

dos Santos, C.A., Horbe, A.M.C., Barcellos, C.M.O., Marimon da Cunha, J.B., 2001. Some structure and magnetic effects of Ga incorporation on $\alpha-\mathrm{FeOOH}$. Solid State Commun. 118, 449-452.

Dükkancı, M., Gündüz, G., Yılmaz, S., Prihod'ko, R.V., 2010. Heterogeneous Fentonlike degradation of Rhodamine 6G in water using CuFeZSM-5 zeolite catalyst prepared by hydrothermal synthesis. J. Hazard. Mater. 181, 343-350.

Esteves, A., Oliveira, L.C.A., Ramalho, T.C., Goncalves, M., Anastacio, A.S., Carvalho, H.W.P., 2008. New materials based on modified synthetic $\mathrm{Nb}_{2} \mathrm{O}_{5}$ as photocatalyst for oxidation of organic contaminants. Catal. Commun. 10, 330-332.

Faust, B.C., Hoigne, J., 1990. Photolysis of Fe(III)-hydroxyl complexes as sources of $\mathrm{OH}$ radicals in clouds, fog and rain. Atmos. Environ. 24, 79-89.

Franch, M.I., Ayllón, J.A., Peral, J., Domènech, X., 2004. Fe(III) photocatalyzed degradation of low chain carboxylic acids: implications of the iron salt. Appl. Catal. B: Environ. 50, 89-99.

Garrido-Ramírez, E.G., Theng, B.K.G., Mora, M.L., 2010. Clays and oxide minerals as catalysts and nanocatalysts in Fenton-like reactions - a review. Appl. Clay Sci. 47, 182-192.

Guimaraes, I.R., Giroto, A., Oliveira, L.C.A., Guerreiro, M.C., Lima, D.Q., Fabris, J.D., 2009. Synthesis and thermal treatment of cu-doped goethite: oxidation of quinoline through heterogeneous fenton process. Appl. Catal. B: Environ. 91, 581-586.

Guimarães, I.R., Oliveira, L.C.A., Queiroz, P.F., Ramalho, T.C., Pereira, M., Fabris, J.D., Ardisson, J.D., 2008. Modified goethites as catalyst for oxidation of quinoline: evidence of heterogeneous Fenton process. Appl. Catal. A: Gen. 347, 89-93.

Haber, F., Weiss, J., 1934. The catalytic decomposition of hydrogen peroxide by iron salts. Proc. Royal Soc. Lond. Ser. A, 332-351.

Haneda, K., Morrish, A.H., 1988. Noncollinear magnetic structure of $\mathrm{CoFe}_{2} \mathrm{O}_{4}$ small particles. J. Appl. Phys. 63, 4258-4260.

Hanna, K., Kone, T., Medjahdi, G., 2008. Synthesis of the mixed oxides of iron and quartz and their catalytic activities for the Fenton-like oxidation. Catal. Commun. 9, 955-959.

Hassan, H., Hameed, B.H., 2011. Oxidative decolorization of Acid Red 1 solutions by Fe-zeolite Y type catalyst. Desalination 276, 45-52.

$\mathrm{Hu}, \mathrm{L}$., Huang, Y., Chen, Q., 2013. $\mathrm{Fe}_{\mathrm{x}} \mathrm{CO}_{3-\mathrm{x}} \mathrm{O}_{4}$ nanoporous particles stemmed from metal-organic frameworks $\mathrm{Fe} 3\left[\mathrm{Co}(\mathrm{CN})_{6}\right]_{2}$ : a highly efficient material for removal of organic dyes from water. J. Alloy. Compd. 559, 57-63.

Hua, M., Zhang, S., Pan, B., Zhang, W., Lv, L., Zhang, Q., 2012. Heavy metal removal from water/wastewater by nanosized metal oxides: a review. J. Hazard. Mater. $211-212,317-331$.

Huang, H.-H., Lu, M.-C., Chen, J.-N., 2001. Catalytic decomposition of hydrogen peroxide and 2-chlorophenol with iron oxides. Water Res. 35, 2291-2299.

Jacobs, J.P., Maltha, A., Reintjes, J.G.H., Drimal, J., Ponec, V., Brongersma, H.H., 1994. The surface of catalytically active spinels. J. Catal. 147, 294-300.

Jentzsch, T.L., Lan Chun, C., Gabor, R.S., Lee Penn, R., 2007. Influence of aluminum substitution on the reactivity of magnetite nanoparticles. Phys. Chem. C 111, 10247-10253.
Katsumata, H., Kaneco, S., Suzuki, T., Ohta, K., Yobiko, Y., 2005. Degradation of linuron in aqueous solution by the photo-Fenton reaction. Chem. Eng. J. 108, 269-276.

Klemeš, J.J., Varbanov, P.S., Huisingh, D., 2012. Recent cleaner production advances in process monitoring and optimisation. J. Clean. Prod. 34, 1-8.

Knapp, J.S., Bromley-Challoner, K.C.A., 2003. 34-Recalcitrant Organic Compounds, Handbook of Water and Wastewater Microbiology. Academic Press, London, pp. 559-595.

Krehula, S., Musić, S., 2006. Influence of Mn-dopant on the properties of $\alpha$-FeOOH particles precipitated in highly alkaline media. J. Alloy. Compd. 426, 327-334.

Krehula, S., Musić, S., Popović, S., 2005. Influence of Ni-dopant on the properties of synthetic goethite. J. Alloy. Compd. 403, 368-375.

Krehula, S., Musić, S., Skoko, Ž., Popović, S., 2006. The influence of Zn-dopant on the precipitation of $\alpha$-FeOOH in highly alkaline media. J. Alloy. Compd. 420, 260268.

Kwan, W.P., Voelker, B.M., 2003. Rates of hydroxyl radical generation and organic compound oxidation in mineral-catalyzed fenton-like systems. Environ. Sci. Technol. 37, 1150-1158.

Lan, Q., Li, F.-b., Sun, C.-X., Liu, C.-S., Li, X.-z, 2010. Heterogeneous photodegradation of pentachlorophenol and iron cycling with goethite, hematite and oxalate under UVA illumination. J. Hazard. Mater. 174, 64-70.

Laville, N., Aït-Aïssa, S., Gomez, E., Casellas, C., Porcher, J.M., 2004. Effects of human pharmaceuticals on cytotoxicity, EROD activity and ROS production in fish hepatocytes. Toxicology 196, 41-55.

Lee, C.S., Joe, Y.H., 2010. Structural and magnetic properties of cu-substituted magnetite studied by using Mössbauer spectroscopy. J. Korean Phys. Soc. 56, $85-88$.

Lee, H.J., Kim, G., Kim, D.H., et al., 2008. Valence states and occupation sites in (Fe, $\mathrm{Mn})_{3} \mathrm{O}_{4}$ spinel oxides investigated by soft x-ray absorption spectroscopy and magnetic circular dichroism. J. Phys. Condens. Matter 20, 295203.

Lei, J., Liu, C., Li, F., Li, X., Zhou, S., Liu, T., Gu, M., Wu, Q., 2006. Photodegradation of orange I in the heterogeneous iron oxide-oxalate complex system under UVA irradiation. J. Hazard. Mater. 137, 1016-1024.

Lelis, M.F.F., Porto, A.O., Gonçalves, C.M., Fabris, J.D., 2004. Cation occupancy sites in synthetic Co-doped magnetites as determined with X-ray absorption (XAS) and Mössbauer spectroscopies. J. Magn. Magn. Mater. 278, 263-269.

Liang, X., Zhong, Y., Zhu, S., He, H., Yuan, P., Zhu, J., Jiang, Z., 2013. The valence and site occupancy of substituting metals in magnetite spinel structure $\mathrm{Fe}_{3-\mathrm{x}} \mathrm{M}_{\mathrm{x}} \mathrm{O}_{4}$ $(\mathrm{M}=\mathrm{Cr}, \mathrm{Mn}, \mathrm{Co}$ and $\mathrm{Ni}$ ) and their influence on thermal stability: an XANES and TG-DSC investigation. Solid State Sci. 15, 115-122.

Liang, X., Zhong, Y., Zhu, S., Ma, L., Yuan, P., Zhu, J., He, H., Jiang, Z., 2012. The contribution of vanadium and titanium on improving methylene blue decolorization through heterogeneous UV-Fenton reaction catalyzed by their codoped magnetite. J. Hazard. Mater. 199-200, 247-254.

Liang, X., Zhu, S., Zhong, Y., Zhu, J., Yuan, P., He, H., Zhang, J., 2010. The remarkable effect of vanadium doping on the adsorption and catalytic activity of magnetite in the decolorization of methylene blue. Appl. Catal. B: Environ. 97, 151-159.

Litter, M.I., 1999. Heterogeneous photocatalysis: transition metal ions in photocatalytic systems. Appl. Catal. B: Environ. 23, 89-114.

Litter, M.I., Blesa, M.A., 1992. Photodissolution of iron oxides. IV. A comparative study on the photodissolution of hematite, magnetite, and maghemite in EDTA media. Can. J. Chem. 70, 2502-2510.

Magalhães, F., Pereira, M.C., Botrel, S.E.C., Fabris, J.D., Macedo, W.A., Mendonca, R., Lago, R.M., Oliveira, L.C.A., 2007. Cr-containing magnetites $\mathrm{Fe}_{3-\mathrm{x}} \mathrm{Cr}_{\mathrm{x}} \mathrm{O}_{4}$ : the role of $\mathrm{Cr}^{3+}$ and $\mathrm{Fe}^{2+}$ on the stability and reactivity towards $\mathrm{H}_{2} \mathrm{O}_{2}$ reactions. Appl. Catal. A: Gen. 332, 115-123.

Matta, R., Hanna, K., Kone, T., Chiron, S., 2008. Oxidation of 2,4,6-trinitrotoluene in the presence of different iron-bearing minerals at neutral pH. Chem. Eng. J. 144, 453-458.

Molina, R., Segura, Y., Martínez, F., Melero, J.A., 2012. Immobilization of active and stable goethite coated-films by a dip-coating process and its application for photo-Fenton systems. Chem. Eng. J. 203, 212-222.

Moura, F.C.C., Araujo, M.H., Costa, R.C.C., Fabris, J.D., Ardisson, J.D., Macedo, W.A.A. Lago, R.M., 2005. Efficient use of Fe metal as an electron transfer agent in a heterogeneous Fenton system based on $\mathrm{Fe}^{0} / \mathrm{Fe}_{3} \mathrm{O}_{4}$ composites. Chemosphere 60, 1118-1123.

Moura, F.C.C., Oliveira, G.C., Araujo, M.H., Ardisson, J.D., Macedo, W.A.A., Lago, R.M. 2006. Highly reactive species formed by interface reaction between $\mathrm{Fe}^{\mathrm{O}}$-iron oxides particles: an efficient electron transfer system for environmental applications. Appl. Catal. A: Gen. 307, 195-204.

Nie, Y., Hu, C., Qu, J., Zhao, X., 2009. Photoassisted degradation of endocrine disruptors over $\mathrm{CuO}_{\mathrm{x}}-\mathrm{FeOOH}$ with $\mathrm{H}_{2} \mathrm{O}_{2}$ at neutral pH. Appl. Catal. B: Environ. 87, $30-36$.

Oliveira, L.C.A., Gonçalves, M., Guerreiro, M.C., Ramalho, T.C., Fabris, J.D., Pereira, M.C., Sapag, K., 2007. A new catalyst material based on niobia/iron oxide composite on the oxidation of organic contaminants in water via heterogeneous Fenton mechanisms. Appl. Catal. A: Gen. 316, 117-124.

Oliveira, L.C.A., Lago, R.M., Rios, R.V.R.A., Augusti, R., Sousa, P.P., Mussel, W.N., Fabris, J.D., 2000. The effect of Mn substitution on the catalytic properties of ferrites. In: Avelino Corma, F.V.M.S.M., José Luis, G.F. (Eds.), Studies in Surface Science and Catalysis. Elsevier, pp. 2165-2170.

Oliveira, L.C.A., Ramalho, T.C., Souza, E.F., Gonçalves, M., Oliveira, D.Q.L., Pereira, M.C., Fabris, J.D., 2008. Catalytic properties of goethite prepared in the presence of $\mathrm{Nb}$ on oxidation reactions in water: computational and experimental studies. Appl. Catal. B: Environ. 83, 169-176. 
Ortiz de la Plata, G.B., Alfano, O.M., Cassano, A.E., 2008. Optical properties of goethite catalyst for heterogeneous photo-Fenton reactions: comparison with a titanium dioxide catalyst. Chem. Eng. J. 137, 396-410.

Ortiz de la Plata, G.B., Alfano, O.M., Cassano, A.E., 2010. Decomposition of 2 chlorophenol employing goethite as Fenton catalyst. I. Proposal of a feasible, combined reaction scheme of heterogeneous and homogeneous reactions. Appl. Catal. B: Environ. 95, 1-13.

Pariente, M.I., Martínez, F., Melero, J.A., Botas, J.A., Velegraki, T., Xekoukoulotakis, N.P. Mantzavinos, D., 2008. Heterogeneous photo-Fenton oxidation of benzoic acid in water: effect of operating conditions, reaction by-products and coupling with biological treatment. Appl. Catal. B: Environ. 85, 24-32.

Pearce, C.I., Henderson, C.M.B., Telling, N.D., Pattrick, R.A.D., Charnock, J.M. Coker, V.S., Arenholz, E., Tuna, F., van der Laan, G., 2010. Fe site occupancy in magnetite-ulvöspinel solid solutions: a new approach using X-ray magnetic circular dichroism. Am. Mineral. 95, 425-439.

Pignatello, J.J., Oliveros, E., MacKay, A., 2006. Advanced oxidation processes for organic contaminant destruction based on the fenton reaction and related chemistry. Crit. Rev. Environ. Sci. Technol. 36, 1-84.

Ramalho, T., Oliveira, L., Carvalho, K., Souza, E., da Cunha, E., Nazzaro, M., 2009. The molecular basis for the behaviour of niobia species in oxidation reaction probed by theoretical calculations and experimental techniques. Mol. Phys. 107, 171-179.

Ramankutty, C.G., Sugunan, S., 2001. Surface properties and catalytic activity of ferrospinels of nickel, cobalt and copper, prepared by soft chemical methods. Appl. Catal. A: Gen. 218, 39-51.

Rocha, E.M.R., Vilar, V.J.P., Fonseca, A., Saraiva, I., Boaventura, R.A.R., 2011. Landfill leachate treatment by solar-driven AOPs. Solar Energy 85, 46-56.

Rodríguez, E., Fernández, G., Ledesma, B., Álvarez, P., Beltrán, F.J., 2009a. Photocatalytic degradation of organics in water in the presence of iron oxides: in fluence of carboxylic acids. Appl. Catal. B: Environ. 92, 240-249.

Rodríguez, E.M., Núñez, B., Fernández, G., Beltrán, F.J., 2009b. Effects of some carboxylic acids on the $\mathrm{Fe}(\mathrm{III}) / \mathrm{UVA}$ photocatalytic oxidation of muconic acid in water. Appl. Catal. B: Environ.1 89, 214-222.

Rusevova, K., Kopinke, F.-D., Georgi, A., 2012. Nano-sized magnetic iron oxides as catalysts for heterogeneous Fenton-like reactions - influence of $\mathrm{Fe}(\mathrm{II}) / \mathrm{Fe}(\mathrm{III})$ ratio on catalytic performance. J. Hazard. Mater. 241-242, 433-440.

Silva, A.C., Cepera, R.M., Pereira, M.C., Lima, D.Q., Fabris, J.D., Oliveira, L.C.A., 2011 Heterogeneous catalyst based on peroxo-niobium complexes immobilized over iron oxide for organic oxidation in water. Appl. Catal. B: Environ. 107, 237-244.

Silva, A.C., Oliveira, D.Q.L., Oliveira, L.C.A., Anastácio, A.S., Ramalho, T.C., Lopes, J.H. Carvalho, H.W.P., Torres, C.E.R., 2009. Nb-containing hematites $\mathrm{Fe}_{2-\mathrm{x}} \mathrm{Nb}_{\mathrm{x}} \mathrm{O}_{3}$ : the role of $\mathrm{Nb}^{5+}$ on the reactivity in presence of the $\mathrm{H}_{2} \mathrm{O}_{2}$ or ultraviolet light. App. Catal. A: Gen. 357, 79-84.

Silva, A.M.T., Zilháo, N.R., Segundo, R.A., Azenha, M., Fidalgo, F., Silva, A.F., Faria, J.L. Teixeira, J., 2012. Photo-Fenton plus Solanum nigrum L. weed plants integrated process for the abatement of highly concentrated metalaxyl on waste waters Chem. Eng. J. 184, 213-220.

Soon, A.N., Hameed, B.H., 2011. Heterogeneous catalytic treatment of synthetic dyes in aqueous media using Fenton and photo-assisted Fenton process. Desalination 269, 1-16.

Sugimoto, T., Matijević, E., 1980. Formation of uniform spherical magnetite particles by crystallization from ferrous hydroxide gels. J. Colloid Interface Sci. 74, 227-243.

Tamimi, M., Qourzal, S., Barka, N., Assabbane, A., Ait-Ichou, Y., 2008. Methomyl degradation in aqueous solutions by Fenton's reagent and the photo-Fenton system. Sep. Purif. Technol. 61, 103-108.
Usman, M., Faure, P., Hanna, K., Abdelmoula, M., Ruby, C., 2012a. Application of magnetite catalyzed chemical oxidation (Fenton-like and persulfate) for the remediation of oil hydrocarbon contamination. Fuel 96, 270-276.

Usman, M., Faure, P., Ruby, C., Hanna, K., 2012b. Remediation of PAH-contaminated soils by magnetite catalyzed Fenton-like oxidation. Appl. Catal. B: Environ. 117$118,10-17$.

Valcárcel, Y., Martínez, F., Gonzalez-Alonso, S., Segura, Y., Catalá, M., Molina, R., Montero-Rubio, J.C., Mastroianni, N., Lopez de Alda, M., Postigo, C., Barcelo, D., 2012. Drugs of abuse in surface and tap waters of the Tagus River basin: heterogeneous photo-Fenton process is effective in their degradation. Environ. Int. $41,35-43$.

Walter, M.V., Vennes, J.W., 1985. Occurrence of multiple-antibiotic resistant enteric bacteria in domestic sewage and oxidative lagoons. Appl. Environ. Microbiol. 50, 930-933.

Wang, X., Liu, C., Li, X., Li, F., Zhou, S., 2008. Photodegradation of 2mercaptobenzothiazole in the $\gamma-\mathrm{Fe}_{2} \mathrm{O}_{3}$ /oxalate suspension under UVA light irradiation. J. Hazard. Mater. 153, 426-433.

Wang, Y., Liang, J.B., Liao, X.D., Wang, L.-S., Loh, T.C., Dai, J., Ho, Y.W., 2010. Photodegradation of sulfadiazine by goethite-oxalate suspension under UV light irradiation. Ind. Eng. Chem. Res. 49, 3527-3532.

Watts, R., Teel, A., 2006. Treatment of contaminated soils and groundwater using ISCO. Pract. Period. Hazard. Toxic Radioact. Waste Manag. 10, 2-9.

Xia, M., Chen, C., Long, M., Chen, C., Cai, W., Zhou, B., 2011. Magnetically separable mesoporous silica nanocomposite and its application in Fenton catalysis. Microporous Mesoporous Mater. 145, 217-223.

Xu, P., Zeng, G.M., Huang, D.L., Feng, C.L., Hu, S., Zhao, M.H., Lai, C., Wei, Z., Huang, C., Xie, G.X., Liu, Z.F., 2012. Use of iron oxide nanomaterials in wastewater treatment: a review. Sci. Total Environ. 424, 1-10.

Xue, X., Hanna, K., Deng, N., 2009a. Fenton-like oxidation of Rhodamine B in the presence of two types of iron (II, III) oxide. J. Hazard. Mater. 166, 407-414.

Xue, X., Hanna, K., Despas, C., Wu, F., Deng, N., 2009b. Effect of chelating agent on the oxidation rate of PCP in the magnetite/H2O2 system at neutral pH. J. Mol. Catal. A: Chem. 311, 29-35.

Yang S, He, H. Wu, D, Chen, D, Liang, X, Oin, Z, Fan, M., Zhu, J., Yuan, P., 2009a Decolorization of methylene blue by heterogeneous Fenton reaction using $\mathrm{Fe}_{3}$ ${ }_{\mathrm{x}} \mathrm{Ti}_{\mathrm{X}} \mathrm{O}_{4}(0 \leq \mathrm{x} \leq 0.78)$ at neutral $\mathrm{pH}$ values. Appl. Catal. B: Environ. 89, 527-535.

Yang, S., He, H., Wu, D., Chen, D., Ma, Y., Li, X., Zhu, J., Yuan, P., 2009b. Degradation of methylene blue by heterogeneous fenton reaction using titanomagnetite at neutral pH values: process and affecting factors. Ind. Eng. Chem. Res. 48, 99159921.

Yeh, C.K.-J., Hsu, C.-Y., Chiu, C.-H., Huang, K.-L., 2008, Reaction efficiencies and rate constants for the goethite-catalyzed Fenton-like reaction of NAPL-form aromatic hydrocarbons and chloroethylenes. J. Hazard. Mater. 151, 562-569.

Yuan, B., Li, X., Li, K., Chen, W., 2011. Degradation of dimethyl phthalate (DMP) in aqueous solution by UV/Si-FeOOH/ $\mathrm{H}_{2} \mathrm{O}_{2}$. Colloids Surf. A: Physicochem. Eng. Asp. 379, 157-162.

Zhong, Y., Liang, X., Tan, W., Zhong, Y., He, H., Zhu, J., Yuan, P., Jiang, Z., 2013. A comparative study about the effects of isomorphous substitution of transition metals ( $\mathrm{Ti}, \mathrm{Cr}, \mathrm{Mn}, \mathrm{Co}$ and $\mathrm{Ni}$ ) on the UV/Fenton catalytic activity of magnetite. J. Mol. Catal. A: Chem. 372, 29-34.

Zhong Y, Liang X., Zhong, Y, Zhu, J., Zhu, S., Yuan, P., He, H., Zhang J., 2012. Heterogeneous UV/Fenton degradation of TBBPA catalyzed by titanomagnetite: catalyst characterization, performance and degradation products. Water Res. $46,4633-4644$ 